University of Louisville

ThinkIR: The University of Louisville's Institutional Repository

Electronic Theses and Dissertations

1948

\title{
A study of Virginia Woolf.
}

Virginia Powell Reid

University of Louisville

Follow this and additional works at: https://ir.library.louisville.edu/etd

Part of the Literature in English, British Isles Commons

\section{Recommended Citation}

Reid, Virginia Powell, "A study of Virginia Woolf." (1948). Electronic Theses and Dissertations. Paper 2118. https://doi.org/10.18297/etd/2118

This Master's Thesis is brought to you for free and open access by ThinkIR: The University of Louisville's Institutional Repository. It has been accepted for inclusion in Electronic Theses and Dissertations by an authorized administrator of ThinkIR: The University of Louisville's Institutional Repository. This title appears here courtesy of the author, who has retained all other copyrights. For more information, please contact thinkir@louisville.edu. 


\section{A STUDY OF VIRGINIA WOOLF}

Submitted to the faculty of the Graduate school of the University of Loulsville in partial fulfillment of the requirements for the degree of Master of Arts January, 1948 by Virginia Powell Reld 
WAME OF STUDENT : VIRGINIA POWELI REID

TITLE OF THESIS: A ETUDY OF VIRGINIA WOOLF

APFROVED BY READING COM ITTEE CO POSED OF THE FOLIO"IHE NGMBERS:

Richard M. Kain

Hilda Threlkeld

NA E OF DIRECTOR, Ernest C. Hassold

DATE: January 30,1948 
CONTENTS

1. Introduction.................... I

2. Background..................... 9

3. Jacob's Room...................... 21

4. Mrs. Dalloway.................... 41

5. To The Lighthouse................ 72

6. The Philosophy of Virginia Woolf....... 100

7. The Style of Virginia Woolf........... 129

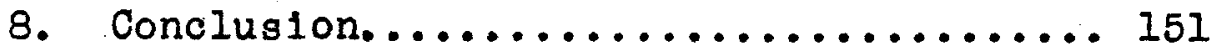


INTRODUCTION

Any needed justification for choosing so prominent a writer as Virginia Woolf for a thesis subject resides In the conviction that generally the treatment accorded her by various orltios has been nelther adequate nor unblased even when there is evident insight into her aims and genius. Too often, one belleves, these critics have stressed merely the new technique and method she developed rather than her presentation of life, which is after all her motivating purpose, or they have over-emphasized her dependence on other contemporary writers.

One of the most comprehensive studies of Virginia Woolf and her works is that by Floris Delattre, who, standing as somewhat of an exception to such criticlsm, more nearly comprehends than any of the others her aptitude and aspirations. His Le Roman Psychologique de V1rginia Woolf, which appeared in 1932, is greatly concerned with the Ilfe of Virginia Woolf as well as the literary and social influences which did much to mold her artistic personality. He summarizes the feminist movement In England, and places Virginia Woolf in a group with Katherine Mansfield and Dorothy Rlchardson. Using both her orftical evaluations and samples of her creative writing as his basis, he sets forth the influence on her 
work of Proust, Joyce, Bergson, and the various Russian writers. An evaluation of those of her novels which had appeared by 1932 follows, and Delattre closes his study with a brief summary of Virginia Woolf's technique and style.

Although his main interest appears to be studying Virginia Woolf in relation to the contemporary literary scene, M. Delattre's evaluation of her novels shows unusual sensitivity to the character relationships and meditative themes which Virginia Woolf presents, for he stresses her interest in the psychological experiences of her characters. Naturally her last two books are not Included, but his interpretations of her earlier works surely would seem to call for a more thorough examination of the real content of Virginia Woolf's novels.

In the same year Joseph Beach's The Twentieth Century Novel appeared, a work of tremendous scope, to be sure, but rather lacking in discernment so far as Virginia Woolf is concerned. At times too prone to generalization, Beach seems to regard Virginia Woolf merely as a parasite upon the technique and method of James Joyce, not recognizing the intrinsic value of her novels:

There are many fundamental points of likeness of her intention and technique to Joyce's, especially in Mrs. Dalloway (1925)..... The artistic problem is much the same for Joyce 
and Mrs. Woolf, and in meeting this problem she has taken many a leaf out of his book. One of the most curious of her imitations of Joyce 18 the incident of the royal automobile in Mrs. Dalloway...... But the author realizes how narrow a range of experience 18 implied in Clarissa Dalloway, her family and friends..... She needs something like the Wandering Rocks eplsode of Ulysses to 1111 the background of her stage..... And 80, like Joyce, she brings in a special section - set off, it is, with breaks in the text - starting with the royal cavalcade, carried over into the ingenious invention of the airplane, and passing on smoothly from one person to another.. Most of these characters never show their noses again. But they have served their purpose of giving to this slice of life breadthwise extension in the present
moment.

Early in 1937 a lengthy article by Herbert Muller appeared in the Saturday Review of Literature ent1tled "Virginia Woolf and Feminine Fiction." Although he recognizes her "mellowness" and her "exquisite artistry," he patronizingly criticizes her so-called lack of vitality; Her characters are all gentle folk, framed in a beautiful little plcture in a cloistered gallery...As creatures of shelter, her characters are too delicate to participate in a really big or intense drama?.... Virginia Woolf and her sisters contribute little but their incidental refinements of method and manner. $n^{3}$

David Dalches devotes a chapter to virginia Woolf in

1. Beach, Joseph, The Twent1eth Century Novel, Pp. 428-432.

2. Muller, Herbert, The Saturday Review of Literature, "Virginia Woolf and Feminte Fiction,"Feb. 6, 1937, p. 4, NB. Reprinted in Modern Fiction (193).

3. Ib1d., p. 16. 
The Novel and the Modern World, whlch was published in 1939. He feels that "she is too much of an escapist, who consistently refused to implicate herself in the twentieth century 'bourgeo1s' world." 4 stating that generally her plots and characters are too rarefled, too far removed Irom this workaday world, he thus dismlsses them and dwells on an intricate analysis of the technique of Mrs. Dalloway, which interests him merely as a "plece of construction" 5 rather than as a novel. Such a view point is all too typical of those who have dealt with Virginia Woolf. Three years later Dalches' book entitled Virginia Woole appeared, which revealed considerably more sympathy and Insight in the psychological and phllosophlcal aspects of her works. After a summary of Virginia Woolf's life, he deals with each of the novels in chronological order, arranging them into four groups: "The Early Novels," Including The Voyage Out and N1ght and Day; "Experiment and Transition," Including Monday or Tuesday; "The SemiTransparent Envelope," Including Jacob's Room, Mrs. Dalloway and To The L1ghthouse; and "Time, Change and Personality," Including the varlegated Orlando, The Waves, The Years, and Between the Acts. A einal chapter on Virginia Woolf's literary criticism emphasizes her wide range of reading and the freshness and eloquence of her discussions.

4. Daiches, David, The Novel and the Modern World, p. 158.
5. Ibid., p. 173. 
E. M. Forster selected the works of Virginia Woolf as the subject for the Rede Lecture, delivered in the Senate House at Cambridge on May 29, 1941. A personal friend of Virginia Woolf's, he rather over-stresses the fact that she wrote for fun, not for money nor for the "sake of Art." He suggests that her whimsical sense of humor and her respect for knowledge and wisdom color her works, as does her poetlc ablilty, but he questions her power to make real her stories and her characters: "She dreams, designs, jokes, invokes, observes detalls, but she does not tell a story or weave a plot, and can she create character?" 6

A more recent study of Virginia Woolf is that by Joan Bennett, published in 1945, which analyzes her books according to characters, storles, morals and form. The chlef criticlsm with this book is that the chapters on characters and storles seem to deal more with how the characters are drawn and how the stories are revealed to the reader rather than with an evaluation of them as they actually are. Then another difficulty with such a study is that it is nearly impossible to analyze each of Virginia Woolf's novels and her two books of criticism in the deserved detall and st1ll keep within some 150 pages.

6. Forster, E. M., VIrginia Woolf, p. 21. 
Between the Acts alone is accorded a separate chapter. The flavor of the varlous novels is accurately imparted, but only with the liberal use of long quotations.

In The Novel and the World's Dilemma, appearing in 1947, Edwin Burgum emphasizes, perhaps overemphasizes, Virginia Woolf's interest in human contacts and social responses. Undoubtedly she was concerned with such problems and with the fallure of the world to encourage more satisfying relationships, but as this is only one phase of her ph1losophy, one wonders whether Mr. Burgum is not limiting her range in an effort to compress her neatly into the scheme of his book. Burgum's consistent references to L1ly Briscoe as "Lucy" and to Jacob Flanders and his mother as "Sanders" surely would cause the reader to question the accuracy of his other appraisals.

Encouragingly enough, the trend in the varlous American criticisms does seem to be growing away from a mere mechanical analysis of form and technique towards a deeper interest in the psychological and philosophical implications of the novels, whtch Delattre emphasized as early as 1932: yet it seems to me that all of these studies are more or less Inadequate, because the storles, the character relations and the meditative themes have been slighted. Any real comprehension and appreciation of Virginia Woolf 
demands a more thorough and inclsive delving into her books. It is not enough to state the fact that Virginia Woolf considered thought more important than action, and so dismiss the actual stories she presents; these after all afford the reason for each novel. Nor is $1 \mathrm{t}$ completely falr to stress too much her form and method, since Virginia Woolf hergelf says:

In any case it is a mistake to stand outside examining "methods." Any method is right, every method 18 right, that expresses what we wish to express, if we are writers; that brings us closer to the novelist's intention $1 f$ we are readers.?

It shall be my purpose, then, to clarify her intention by bringing into the foreground her storleg along with the philosophy of life that she wishes to present, and at the same time to exhibit as fully as possible her style and her method. Thus for this study I have chosen three of Virginia Woolf's books: Jacob's Room (1923), Mrs. Ealloway (1925), and To The Lighthouse (1927); the first because in thought and technique it is introductory to the later books, and the other two because to me they not only represent the apex of her 11 terary efforts, but also deserve a permanent place w1 th the best of contemporary wr1tings.

F1rst of all I shall seek to summarize the background of Virginia Woolf, including her own expressed alm in

7. Woolf, V1rginia, The Common Reader, p. 215. 
writing as it is carried out in all of her novels. Then a more detalled analysis of the psychology, the characters and the plot of the three chosen books will follow in a further effort to evaluate the effectiveness of her presentation of 11fe 1tself. Next will come a discussion of the phllosophy and values reflected throughout her novels, and finally a study of her uniquely developed style which is necessary for thoroughly revealing Virginia Woolf, the writer. 


\section{BACKGROUND}

The famlly life and home setting of Virginia Woolf are manifested in varlous ways throughout her novels. Her outspoken respect for intelligence and scholarship, her general pre-occupation with the higher class of English soclety, and above all her fascination with the problems of I1fe and death are but revelations of her own Inner belng. 1

Virginia Woolf's life was that of an upper middle class Englishwoman of the 1ntelligentsia. She was born In 1882, the daughter of S1r Leslie Stephen, who was extremely well known in his day as an author, editor and blographer. His agnosticism prevented him from receiving a professorsh1p at Cambridge and he thus settled down to a life of writing. He published over thirty volumes, of which perhaps the best known are his History of English Thought in the Elghteenth Century in two volumes, and The Dictionary of National Blography which he planned and edited, and to which he contributed 320 articles.

1. Blographical material concerning Virginia Woolf is presented by David Dalches in V1rginia Woolf and by Floris Delattre in Le Roman Psychologlque de V1rginia Woolf, Both of which have al ready been discussed; virtually the same data are avaliable in Terence Holliday's Introduction to the Modern Library edition of To The L1ghthouse and in Kunitz' and Haycraft's Twentieth Century Authors. From the se sources I shall take those facts which are of interest to the study of Virginia Woolf's fiction. 
Born into a large family, Virginia was the third chlld of her father's second marrlage. Leslle Stephen's first wife, the daughter of Thackeray, died after giving birth to her only child. A lew years later, Stephen married the charming and beautiful Mrs. Julia Prinsep Duckworth who bore hlm four children: Vanessa, Jullan, Virginia and Adrian. As the second Mrs. Stephen had children by her former marriage, Virginia was brought up In the midst of a large family, without the formal restrictions of education and training that were usual in the late victorian era. Her comprehensive though informal education largely consisted in her use of and devotion to her father's huge library whlch included the widest range of classical and contemporary works. As a complementary addition to her educational background, she also became quite intimately acqualnted with the leading I1terary figures of England at that time through contacts with them in her father's home.

Following the death of their parents and the marriage of Vanessa, Virginia and her brother Adrian bought a home together in 1907, and it was here that the literary "Bloomsbury Group" had its beginning in the frequent gathering together of such people as Charles Tennyson, Katherine Mansfield, Lytton Strachey, Desmond Macarthy and Clive Bell. During these early years Virginla began 
her career as a literary critic and became a reviewer for the London Times Literary Supplement. Her essays also were widely published in both British and American magazines.

At the age of 30 , she marrled Leonard Woolf, a Cambridge graduate who had returned to London after serving for some jears in the British Civil service of Ceylon. Although his primary activities have been concerned with literary work, both writing and publishing, his varied other interests have included economics, the labor movement, and politics.

The Woolfs founded the Hogarth Press in 1917, beginning modestly with hand set pamphlets and working up into a large and successful company which eventually published Virginia Woolf's own novels. Although both of them were busy with this joint enterprise as well as their own writings, they still found time for the informal meetings w1th their friends. W1lliam Plomer describes Virginia Woolf at such a gathering:

It was therefore not surprising to see her, at one time and another, in that upper room in Tavistock Square, happy in the company of, for example, Lytton Strachey, Lowes Dickinson, Roger Fry, E. M. Forster, T. S. Ellot, Stephen Spender, Ellzabeth Bowen, or Rosamund Lehmann. She had a great gift for making the young and obscure feel that they were of great value too; she admired physical as well as intellectual beauty; she could charm away diffidence; and she could be notably sympathet1c with young 
women, particularly young women from Cambridge. A strong sense of the proper functions of ilterature and the Importance of taste gave her a proper pride (derived doubtless in part from her literary father and background) in her own gifts, but she was absolutely w1 thout arrogance. 2

Dissatisfied with mere critical work, Virginia Woolf next moved into the fleld of flction, where her preoccupation with the inner feelings and with sensation rather than ldeas could be more readily emphasized. Her f1rst novel, The Voyage Out, was published in 1915. This story is concerned with a young girl, Rachel Vinrace, who accompanies her aunt and uncle on a trip to Santa Marina, falls in love, but dies of a tropical fever. In 1919 Virginia Woolf's second novel, Night and Day, appeared. Again the central character is a young woman, Katharine Hilbery, but this time, perhaps following Virginia Woolf's own pattern, the heroine is much more intellectual, poised and experlenced. Engaged to one young man, she falls in love with another, Ralph Denham, and eventually plans to marry h1m.

These few facts about the plots fall entirely to convey the essence of the novels, which is concerned with the vital human experlences of love, happiness, loneliness and death. V1rginia Woolf even in these traditional novels seems much more interested in speculation, as she

2. Dalches, Dav1d, Virginia Woolf, p. 6 . 
ties in the past with the present, and as she pictures the reactions of characters to each other rather than in methodically moving from an introduction to a climax and on to a conclusion.

In her effort to find a better medium for her storles, she published in 1920 a group of elght sketches entitled Monday or Tuesday. These are more stylistic exercises than short stories, for she tries to convey moods, impressions and atmosphere in a sort of flowing, melodic prose.

Virginia Woolf's "Essay on Modern Fiction," which appeared as a part of her first book of literary criticism, The Common Reader, in 1925, sheds light on her alm in writing and on her struggle for self-expression. In a discussion of the works of Wells, Bennett and Galsworthy, she concludes that the label of materialism is applicable to them, "That they write of unlmportant things, that they spend immense skill and immense industry making the trivial and the transitory appear the true and the enduring. " 3

Such an outlook, according to Virginia Woolf, is quite artificial, for 1t presents such a blased view of Iife that life itself escapes. "Whether we call it life or spirit, truth or reality, this, the essentlal thing, has moved off, or on." 4 she criticizes the modern novellsts,

3. Woolf, Virginia, The Common Reader, p. 210.

4. Ibid., p. 212 . 
herself included, who follow these neat, conventional means of expression which fall entirely to present life as it 1s, full of complexity and 1rrationality:

We go on perseveringly, consclentiously, constructing our two and thirty chapters after a design which more and more ceases to resemble the vision in our minds... But sometimes, more and more often as time goes by, we suspect a momentary doubt, a spasm of rebellion, as the pages fill themselves in the customary way. Is life like this? Must novels be like this? Look within and $11 f e$, it seems, is very far from being 'like this.' Examine for a moment an ordinary mind on an ordinary day. The mind receives a myriad impressions - trivial, fantastic, or engraved with the sharpness of steel. From all sides they come, an incessant shower of innumerable atoms..... Life is not a series of gig lamps symetrically arranged, but a luminous halo, a semi-transparent envelope surrounding us from the beginning of consclousness to the end. Is it not the task of the novelist to convey this varying, this unknown and uncircumscribed spirit, whatever aberration or complexity it may display, with as ilttle mixture of the alien and external as possible? 5

Her determination is, then, to present the inner I1fe rather than the outer, the psychological rather than the materialistic reality, and by recognizing the 1mportance of all experience and contact, to help penetrate the "luminous halo": "Let us record the atoms as they fall upon the mind in the order in which they fall, let

5. Woolf, Virginia, The Common Reader, p. 212-213. 
us trace the pattern, however disconnected and incoherent in appearance, which each sight or incident scores upon the consclousness." 6 she stresses the fact that there Is no set subject matter that must or must not be included in a novel, for "everything is the proper stuff of fiction, every feeling, every thought, every quality of brain and spirit is drawn upon."7 To be discarded, then, was the traditional pattern of The Voyage Out and N1ght and Day in favor of the expressionistic presentation of Jacob's Room and her later novels. Of course, Virginla Wools does follow some policy of selection, for her very desire to set down the essence of experience necessitates an order and discipline. As she states in Jacob's Room, "The observer is choked with observations... The difficulty remains - one has to choose. $1^{8}$

In 1922 Jacob's Room appeared, the first of her novels to make use of her more fluid and expressive manner of presentation:

There is no attempt here to preserve the I1rm outlines of chronological events; experience $1 \mathrm{~s}$ broken down into a serles of rapidiy dissolving impressions which merge into one another but which are kept from complete dissolution by the meditative eye of the author, who keeps the flux of

6. Ibid., p. 212.

7. Ib1a., p. 213.

8. Woolf, Virginia, Jacob's Room, p. 113. 
things constantly in sight, and preserves her own character suffiolently to be able to comment intermittently on the intang $1-$ ble nature of her subject. 9

More carefully bound together and much more effectlve 1s Mrs. Dalloway, which appeared in 1925. Th1s book and To The Lighthouse which followed it in 1927 w11l be discussed in detall later. Suffice it to say that in these novels Virginia Woolf seems to have discovered what was for her the most satisfactory medium for setting forth her storles and her meditations.

A complete change can be noted in the fanciful, whimsical Orlando, (1928), which has been interpreted by Dav1d Dalches and Floris Delattre as the story of Virginia Woolf's Iriend, Victorla Sackville-West. On the other hand, Joseph Beach suggests that while it is possible to regard Orlando as a history of English literature, he is "inclined to consider it a study in multiple personality. "10

The story is the blography of the title person during a period of some 350 years, during which time Orlando becomes a woman. Regardless of his real occupation at the t1me, Orlando always secretly destres to be an author, and wrltes in the varying styles of each generation. Written in a light vein, the story is mainly memorable for its

9. Dalches, Dav1d, Virginia Woolf, p. 55. 10. Beach, Joseph, op. c1t., p. 491 . 
beautiful descriptive passages.

Virginia Woolf's most severely disciplined work is The Waves, which was published in 1931. This book is made up of a serles of monologues of six characters, Susan, Jinny, Rhoda, Lou1s, Neville and Bernard, who are followed as they think about themselves and each other from childhood unt1l midale age. A seventh character, Percival, never directly introduced, is seen only through the thoughts of the original six. Such formal, artificial presentation is somewhat reminiscent of drama in which each character comes forward alone and speaks his piece, and is perhaps too stilted to be especially rewarding.

The Years, published in 1937, is the story of the Parglter family from 1880 to 1930; the novel begins with the 1llness and death of Mrs. Pargiter, and ends with a party given by Delia, one of the Parglter chlldren. While the book is more traditional as concerns plot, report of conversations, and insight into the minds of the characters, Virginia Woolf retains her lyrical prose, her delicate and whimsical touch in this novel whlch traces the postwar deterioration of England as well as that of the Pargiters.

Her last novel, Between the Acts, was published posthumously in 1941. Again the action takes place in 
one day and is concerned with a group of people in rural England who are giving their annual pageant. The play portrays the development of England from its early days to the present time. The shadow of the coming war, the general lack of understanding of the audience concerning the play, the petty cares of the individuals all combine to give an impression of frustration and of incompletion. Apparently this very feeling of frustration and of despair was an integral part of Virginia Woolf's own experience, for her life ended by sulc1de in April, 1941. Her husband revealed that she had suffered periods of severe depression, and was constantly haunted by the fear that she might endure another mental breakdown such as one she had experienced during the first World War. Before she walked down and into the River Ouse, she wrote to her husband: "I feel certain that I am going mad again. I feel we can't go through another of those terrible times. And I shan't recover this time." 11

Quite possibly she was depressingly influenced by the tragic example of her very dear friend Roger Fry's wife, who became insane and spent the last 27 years of her ilfe in a mental institution. At any rate the themes

11. Dalches, Dav1d, Virginia Woolf, p. 201. 
of death, of 1088 of vitallty and of sulclde occur again and again in her books. Mrs. Dalloway herself, having recovered from a long 1llness, can hardly decide whether Iffe is worth the necessary effort, and is tremendously moved by the sulclde of the young war-crazed Septimus Sm1th. Rachael V1nrace dies after an 1llness, Jacob Flanders 18 killed in the war as 18 Andrew Ramsay, and Mrs. Ramsay dies quite unexpectedly. The secret antlcipation of recurrent madness, the horrors of the war, along with a despalr as to the value of life and a fear of the terrors of living - all these combined to bring about Virginia Woolf's sulcide.

Thus Virginia Woolf's books seem to have been written in an effort to reveal her vision of life and generally reflect her preoccupation with certain recurring themes. These would include the momentous problems of life, love and death, the conflict between generations, and the relationship of the individual to himself, to others, and to the changling life of England. While current experiences are often interpreted in the light of the past, there is very rarely left an impression of hope or of vision into the future. The more detalled studies of Jacob's Room, Mrs. Dalloway, and To The Lighthouse will endeavor to point out the flow of the plot and the relationships of the characters, while the chapter on Virginia Woolf's 
$-20-$

phtlosophy will trace these repeated themes. 


\section{JACOB'S ROOM}

Struck w1th V1rginia Woolf's new approach, David Dalches says: "It would be possible, but scarcely profitable, to analyse the 'plot' of Jacob's Room. The book was written for the sake of the Impressions, of the fluid rendering of experience - one might say for the sake of style." I Admitting that the plot is very loosely constructed, such a statement seems to be lacking in discernment. To say that VIrginia Woolf wrote a book for the sake of style would be to horrify Virginia Woolf, for she herself says: "The more successful the method, the less 1t attracts attention. The reader 1 t $1 \mathrm{~s}$ to be hoped will not give a thought to the book's method or to the book's lack of method. He is concerned only with the effect of the book as a whole on his mind. "2

True enough, the effect of Jacob'g Room as a whole is somewhat startling. As E. M. Forster states, "The 1 mprobable has occurred; a method essentially poetic and apparently trifling has been applied to flction." 3 The book is a series of eplsodes, conversations and essays,

1. Dalches, David, op. c1t., p. 61.

2. Woolf, V1rginia, Mrs. Dalloway, Introduction, p. v111

3. Forster, E. M., Virginia Woolf, p. 14. 
all bound around the central figure of Jacob Flanders, as seen by his mother, his friends and his sweethearts, from his childhood through school days until his death in the war. Instead of the usual descriptions of his appearance, h1s thoughts, and h1s "character", the reader must fashion Jacob through the Impression he makes on the other characters and through his reactions to them. Virginia Woolf's feeling that life is made up of "an Incessant shower of innumerable atoms" rather than a carefully planned set of events in logical sequence is demonstrated by the disregard for tradtional plot development and by the variety of rather disconnected scenes of varying length.

The book rather casually opens with Betty Flanders living in Cornwall with her three young sons, Archer, Jacob and baby John. In writing to her friend, Captain Barfoot, her letters reflect her sadness:

Such were Betty Flanders's letters to Captaln Barfoot - many paged, tear stalned. Scarborough is seven hundred miles from Cornwall; Captain Barfoot is in Scarborough; Seabrook 18 dead. Tears made all the dahlias in her garden undulate In red waves and Plashed the glass house in her eyes, and spangled the kitchen with bright knives, and made Mrs.Jarvis, the rector's wife, think at church, whlle the hymn-tune played and Mrs. Flanders bent low over her little boys' heads, that marriage is a fortress and widows 
stray solitary in the open flelds, plcking up stones, gleaning a few golden straws, lonely, unprotected, poor creaturea. Mrs. Flanders had been a wldow the se two years. 4 .

Indeed Betty Flanders does feel the welght of her duties. The fear of the coming storm, "the agitation and vitality of nature stirred Betty Flanders and made her think of responsibility and danger. "5 she never conslders marrying again, although she does recelve a proposal from the Rev. Mr. Floyd, who kindly teaches the boys Latin in his spare time. But her note of refusal was "such a motherly, respectful, inconsequent, regretful letter that he kept it for many years. " 6

Captain Barfoot through the years remains a loyal frlend, always making his regular Wednesday afternoon visit, as he had for some twenty years, in splte of his invalld wife. W1th him Betty acted "as $1 f$ she were very confident, very fond of the Captain, and a great many years younger than he was. Indeed in her blue apron she did not look more than 35. He was well over 50." ?

During these early years Jacob is seen merely as a busy little boy, hunting for crabs, linding a cow's skull, sleeping exhaustedly. Only glimpses of him are given,

4. Woolf, Virginia, Jacob's Room, p. 4-5.

5. P. 11 .

6. P. 29.

7. P. 42 . 
not especially distinguishing him from his brothers, so that the reader has a conventional impression of a normal, happy chlldhood. Rather independent in his ways, he often becomes fascinated with butterflies, badgers or whatever his current interest may be, so that he is late getting home, "the only one of her sons," according to Betty, "who never obeyed her." 8 Rather lelsurely and pleasantly his boyhood passes until "Jacob Flanders, therefore, went up to Cambridge in October, 1906." 9

On h1s way to Cambridge, he 18 covertly watched by Mrs. Norman, who although she 1s flfty years old, and the mother of a grown son, 18 rather fearful of "being shut up alone, in a rallway carriage, with a young man. "10 Her observation of him is typical of the way Jacob is presented to the reader and of the way Virginia Woolf dismisses any attempt to sum up another Individual:

Taking note of socks (loose), of tie (shabby), she once more reached h1s face. She dwelt upon his mouth. The lips were shut. The eyes bent down, since he was reading. All was $11 \mathrm{rm}$, yet youthful, indifferent, unconsclous as for knocking one down! No, no, no! She looked out of the window, smiling slightly now, and then came back again, for he didn't notlce her. Grave, unconscious.. now he looked up, past her... he seemed so out of place, somehow, alone with an elderly lady... then he

8. P. 32 .

Q. P. 43 .

10. P. 44. 


\begin{abstract}
flxed his eyes - which were blue on the landscape. He had not realized her presence, she thought. Yet 1t was none of her fault that this was not a smoking carriage - if that was what he meant.

Nobody sees any one as he 1s, let alone an elderly lady sitting opposite a strange young man in a raliway carriage. They see a whole - they see all sorts of things - they see themselves..... But since, even at her age, she noted his indifference, presumably he was in some way or other - to her at least nice, handsome, interesting, distinguished, well bullt, like her own boy? One must do the best one can with her report. Anyhow, this was Jacob Flanders, aged nineteen. It is no use trying to sum people up. One must follow hints, not exactly what is sald, nor yet entirely what is done - for instance, when the train arew into the station, Mr. Flanders burst open the door, and put the lady's dressing-case out for her, saying, or rather mumbling: "Let me" "very shyly: Indeed he was rather clumsy about 1 t. 11
\end{abstract}

A glimpse of Jacob in chapel, pondering on why women are admitted to the services, winking solemnly at his frlend Timmy Durrant, is followed by a rather painful meal at the home of Professor Plumer. Youthfully superior and 1mpudent, he celebrates h1s escape with the comment "Bloody beastly", "summing up his discomfort at the world shown him at lunchtime, a world capable of existing - there was no doubt about that - but so unnecessary, such a thing to belleve in - Shaw, Wells and the

11. P. 45-46. 
serious sixpenny weeklies! What were they after, scrubb1ng and demollshing, these elderly people? Had they never read Homer, Shakespeare, the Ellzabethans? 12

The lyricism mixed with narrative characteristic of Virginia Woolf's writing is shown by a section concerning Jacob's night studies which is introduced by this nearpoetry:

The feathery white moon never let the sky grow dark; all night the chestnut blossoms were white in the green; dim was the cowparsley in the meadows. 13

In the same delioate veln 18 her description of "the springy alr of May, the elastic air with its particles chestnut bloom, pollen, whatever it is that gives the May air its potency,blurring the trees, gumming the buds, daubing the green. "14

A feeling of well belng, of complacency seems to exude from Jacob during these college days. In the intense, delightrul, endless sessions which always take place between earnest students, he 1 s equently an active particlpant:

"Well, you seem to have studied the subject, sald Jacob, rising and standing over S1meon's chalr. He balanced himself: he swayed a little. He appeared extra-

12. P. 54.

13. P. 59.

14. P. 56. 
ordinarily happy, as if his pleasure would brim and spill down the sides if simeon spoke. Simeon sald nothing. Jacob remained standing. But intimacy - the room was full of 1t, st1ll, deep, like a pool. W1thout need of movement or speech $1 t$ rose softly and washed over everything, mollifying, kindling, and coating the mind with the lustre of a pearl, so that if you talk of a light, of Cambridge burning, 1t's not languages only. It's Julian the Apostate. 15

The object of Jacob's joung, most innocent love is introduced at a dinner party given for Jacob and Timmy by Mrs. Durrant:

"Oh, Clara, Clara!" exclaimed Mrs. Durrant, and Timothy Durrant adding, "Clara, Clara." Jacob named the shape in yellow gauze Timothy's sister, Clara. The girl sat smlling and flushed. W1th her brother's dark eyegs she was vaguer and softer than he was. 16

During his brief visit, however, romance has little chance to thrive and his last conversation with Clara at this time ends "not with a bang but a whimper":

"I have enjoyed myself," sald Jacob, looking down the green house. "Yes, it's been delightful," she sald vaguely.

"Oh, Miss Durrant, he sald, taking the basket of grapes; but she walked past him towards the door of the greenhouse. "You're too good - too good," she thought, thinking of Jacob, thinking that he must not say that he lovea her. No, no, no.

15. P. 73.

16. P. 93 . 
The chlldren were whirling past the door, throwing things high into the air. "Little demons!" she crled. "What have they got?" she asked Jacob. "Onions, I think," sald Jacob. He looked at them without moving. 17

Nevertheless Clara thinks of him often, falthfully remembering him in her diary, soulfully pouring out her heart while 1ronically at the same moment Jacob and his friends are laughing at indecent storles:

"I like Jacob Flanders," wrote Clara Durrant in her dlary. "He is so unworldly. He gives himself no airs, and one can say what one likes to him, though he's erightening because..." But Mr. Letts allows little space in his shilling diarles. Clara was not the one to encroach upon Wednesday. Humblest, most oand1d of women! "No, no, no," she sighed, standing at the greenhouse door, "don't break - don't spoll" - what? Something Infinitely wonderful. But then, this is only a young woman's language, one, too, who loves, or refrains from loving. She wished the moment to continue for ever precisely as it was that July morning. And moments don't. Now, for instance, Jacob was telling a story about some walking tour he'd taken, and the inn was called "The Foaming Pot," which, considering the landlady's name... They shouted with laughter. The joke was indecent. 18

A good deal of Jacob's time in London, where he has rooms, is taken up with Florinda, a gem of doubtful purity, "who talked more about virginity than women mostly do; and

17. P. 102.

18. P. 17 . 
had lost 1t only the night before, or cherished it beyond the heart in her breast, according to the man she talked to." 19 Jacob belleves in her chastity, :W1ld and frall and beautiful she looked, and thus the women of the Greeks were, Jacob thought; and this was 11fe; and himself a man and Florinda chaste." 20 His gift to her of Shelley's works, however, proves rather a 1lop, and it "did occur to Jacob, halfway through dinner, to wonder whether she had a m1nd. 121

Jacob's affair with Florinda is also presented from his mother's viewpoint. She has written a letter to him, typical of the letters full of inconsequential small talk which "mothers down at Scarborough scribble over the fire with their feet on the fender, when tea's cleared away, and can never, never say, whatever it may be - probably this - Don't go with bad women, do be a good boy; wear your thlok shirts; and come back, come back, come back to me."22 Her letter 11 es ignored on the hall table as Jacob and Florinda enter the bedroom:

But if the pale blue envelope lying by the biscuit-box had the feelings of a mother, the heart was torn by the little creak, the sudden stir. Behind the door was the obscene thing, the alarming presence,

19. P. 18.

20. P. 19.

21. P. 20.

22. P. 151. 
and terror would come over her as at death, or the birth of a child. Better, perhaps, burst in and face it than sit in the antechamber 11 stening to the 11ttle creak, the sudden stir, for her heart was swollen, and pain threaded 1 t. My son, my son - such would be her cry, uttered to hide her vision of him stretched with Florinda, inexcusable, irrational, in a woman with three chlidren living at soarborough. And the fault lay with Florinda. Indeed, when the door opened and the couple came out, Mrs. Flanders would have flounced upon her only it was Jacob who came first, in his aressing-gown, amlable, authorltative, beautifuliy healthy, like a baby after an alring, with an eye clear as running water. Fiorinda followed, lazily stretching; yawning a little, arranging her hair at the looking-glass - while Jacob read his mother's letter. 23 .

His feeling for Florinda suffers a sudden shock, however, for just as he is philosophlzing that lhese little prostitutes, staring in the fire, taking out a powder-puff, decorating $11 \mathrm{ps}$ at an inch of looking-glass, have (so Jacob thought) an inviolable f1del1ty, "24 he sees her walking along the street holding onto another man's arm:

It was as if a stone were ground to dust; as if white sparks flew from a livid whetstone, whioh was his spine; as if the switchback rallway, having swooped to the depths, fell, fell, fell. This was in his face. Whether we know what was in his mind is another question. Granted ten years'

23. P. 153-154.

24. P. 158 


\begin{abstract}
seniority and a difference of sex, fear of him comes first; this is swallowed up by a desire to help - overwhelming sense, reason, and the time of night; anger would follow close on that - with Florinda, w1th destiny; and then up would bubble an 1rresponsible optimism. "Surely there's light enough in the street at this moment to drown all our cares in gold!" Ah, what's the use of saying 1t? Even while you speak and look over your shoulder towards Shaftesbury Avenue, destiny is chipping a dent in him. He has turned to go. 25 .
\end{abstract}

And indeed he seems remarkably unscarred from this distllusioning experience. Shortly after this and from Mrs. Papworth, cook, washwoman, general housecleaner, the reader hears rather than sees "Mr. Sanders", as she mistakenly calls him, engaged in heated discussion with Richard Bonamy, w1th h1s usual exuberance and determination:

As she held the plates under water and then dealt them on the pile beneath the h1ssing gas, she listened: heard sanders speaking in a loud rather overbearing tone of volce: "good" he said, and "absolute" and "Justice" and "punishment," and "the w11l of the major1ty." Then her gentleman piped up; she backed him for argument against Sanders; Yet Sanders was a line young lellow..... Putting the plates in the rack she heard once more Sanders at it again ("He don't give Bonamy a chance," she thought). "Objective something," sald Bonamy; and "common ground" and something else - all very long words, she noted. "Book learning does 1t," she thought to herself..... "Tomorrow's breakfast, sir," she sald,

25. P. 158-159 
opening the door; and there were Sanders and Bonamy like two bulls of Bashan driving each other up and down, making such a racket, and all them chalrs in the way. They never noticed her. She felt motherly towards them. "Your breakfast, sir," she sald, as they came near. And Bonamy, all his halr touzled and his tie flying, broke off, and pushed Sanders into the arm-chair, end sald Mr. Sanders had smashed the coffee-pot and he was teaching Mr. Sanders - Sure enough, the coffee-pot lay broken on the hearthrug. 26.

Th1s galety of spirit, this zest for living seems generally to accompany Jacob, so that even the commonplace and ordinary take on a special glow. His youth, his confidence in himself and in his friends all contribute to his contented mood:

The magniflcent world - the 11ve, sane, vigorous world... These words refer to the stretch of wood pavement between Hammersmith and Holborn in January between two and three in the morning. That was the ground beneath Jacob's feet. It was healthy and magnificent because one's room, above a mews, somewhere near the river, contalned fifty excited, talkative, friendly people. And then to stride over the pavement (there was scarcely a cab or policeman in sight) is of itself exhilarating. The long loop of Piccadilly, diamondstitohed, shows to best advantage when 1t is empty. A young man has nothing to fear. On the contrary, though he may not have said anything brilliant, he feels pretty confident he can hold his own. He was pleased to have met Mangin; he admired the young woman on the floor; he liked them all; he liked

26. P. 169-170-171. 
that sort of thing. In short, all the drums and trumpets were sounding. The street scavengers were the only people about at the moment. It is scarcely necessary to say how well-d1sposed Jacob felt towards them; how it pleased him to let himself in with his latch-key at his own door; how he seemed to bring back with him into the empty room ten or eleven people whom he had not known when he set out; how he looked about for something to read, and found 1 , and never read $1 t$, and $f e l l$ asleep. 27.

Another young woman, Fanny Elmer, comes into Jacob's Iife simply by passing under his window as he plays chess. Later she is introduced to him by Nick Branham, the artist for whom she models. With romance glowing in her soul, she overlooks Jacob's awkwaraness in favor of his beautiful volce, and just that suddenly falls in love with him:

She thought how I1ttle he said yet how firm 1t was. She thought how young men are dignifled and aloof, and how unconsclous they are, and how quietly one might sit beside Jacob and look at him. And how chlidlike he would be, come in tired of an evening, she thought, and how majestic; a little overbearing perhaps; "But I wouldn't give way," she thought... Her screwed-up black glove dropped to the floor. When Jacob gave 1t to her, she started angrily. For never was there a more irrational passion. And Jacob was afraid of her for a moment so violent, so dangerous is it when young women stand rigid; grasp the barrier; fall in love. 28

27. P. 188-189.

28. P. 198-200. 
Extremely sentimental, Fanny's love colors her whole existence. She imagines the little children in the park to be hers, she wonders at the joy of the singing thrush. For Jacob's sake she buys a copy of Tom Jones: "For this dull stuff (Fanny thought) about people with odd names is what Jacob l1kes. Good people like 1t. Dowdy women who don't mind how they cross their legs read Tom Jones - a mystic book. "29 However, even her rather misleading statement "I do like Tom Jones"30 does not induce Jacob to reclprocate her affection. On the contrary, he plans to leave Fanny and London to take a trip to Greece, "For, he said, there is nothing so detestable as London in May. "31

Fanny thought it all came Irom Tom Jones. He could go alone with a book in his pocket and watch the badgers. He would take a train at elght-thirty and walk all night. He saw fireflies, and brought back glow-worms in p1ll-boxes. He would hunt with the New Forest Staghounds. It all came from Tom Jones; and he would go to Greece with a book in h1s pocket and forget her. 32 .

Jacob is seen briefly in Paris at a cafe, w1th some new friends discussing Shakespeare, who, he declares, "had more guts than all these damned frogs put together. "33 Informally Virginia Woolf continues:

29. P. 207 .

30. P. 208 .

31. P. 209.

32. P. 210.

33. P. 212 . 
Well, not a word of this was ever told to Mrs. Flanders; nor what happened when they paid the bill and left the restaurant, and walked along the Boulevard Raspallle. Then here $1 \mathrm{~s}$ another scrap of conversation; the time about eleven in the morning; the scene a studio; and the day Sunday. 34

So Jacob is again seen with hls frlends, Mallinson, Cruttendon, and Jinny Carslake, who is in love with Cruttendon. Parls life seems wonderfuliy romantic and fascinating to him: "Jacob had nothing to hide from his mother. It was only that he could make no sense himself of his extraordinary excitement, and as for writing it down - ." 35

On the train going to Greece, Jacob feels quite selfsatisfled, picturing his future conversation with Bonamy:

St111, to be travelling on one's own with a hundred pounds to spend is a fine affair. And 11 his money gave out, as 1t probably would, he would go on foot. He could live on bread and wine - the wine in straw bottles - for after doing Greece he was going to knock off Rome. The Roman civilization was a very inferior affair, no doubt. But Bonamy talked a lot of rot, all the same. "You ought to have been in Athens," he would say to Bonamy when he got back. "standing on the Parthenon, "he would say, or "The ruins of the Coliseum suggest some falrly sublime reflections," which he would write out at length in letters. It might turn to an essay upon clvilization. A comparison between the ancients and moderns, with

34. P. 215.

35. P. 222. 
some pretty sharp hits at Mr. Asquith something in the style of G1bbon. 36

However, the corset advertisements, the 1ll-behaved children and the bad smelling cheese somewhat disillusion him concerning Greece, so that his gloom is felt even by Bonamy who slghs as he reads Jacob's letter:

And he sighed again, being indeed so profoundly gloomy that gloom must have been lodged in him to cloud him at any moment, which was odd in a man who enjoyed things so, was not much given to analysis, but was horribly romantic, of course, Bonamy thought, in his rooms in Lincoln's Inn.

"He will fall in love," thought Bonamy. "Some Greek woman w1th a stralght nose! "37

But then Jacob Flanders was not at all of his own way of thinking - far from 1t, Bonamy sighed, laying the thin sheets of notepaper on the table and falling into thought about Jacob's character, not for the first time. The trouble was this romantic vein in him. "But mixed with the stupidity which leads him into these absurd predicaments, "thought Bonamy, 'there 1 s something something' - he sighed, for he was fonder
of Jacob than of any one in the world. 38

Sure enough, Jacob finds considerable comfort in the person of Mrs. Sandra Wentworth W1lliams, who looks "very beautiful, tragic, and exalted." 39

How beautiful the evening was! and her beauty was 1 ts beauty. The tragedy of Greece was the tragedy of all high sould.

36. P. 229-230.

37. P. 237.

38. P. 238.

39. P. 240. 
The Inevitable compromise. She seemed to have grasped something. She would write 1t down. And moving to the table where her husband sat reading she leant her chin in her hands and thought of the peasants, of suffering, of her own beauty, of the inevitable compromise, and of how she would write it down..... "Every thing seems to mean so much," sald Sandra. But with the sound of her own volce the spell was broken. She forgot the peasants. Only there remained with her a sense of her own beauty, and in front, luckily, there was a looking-glass. 46

Her dellcacy, her dignity, and her sadness impress Jacob greatly; he yearns to protect her, and as she tells h1m about her motherless chlldhood, "Jacob thought that if he had been there he would have saved her; for she had been exposed to great danger, he felt." 41

On her part, Sandra does want something from Jacob:

For she could not stop unt1l she had told him - or heard him say - or was it some action on his part that she required? Far away on the horlzon she discerned it and could not rest... "But," she asked herself, "what do I want Irom him? Perhaps it is something that I have missed..."42

In farewell, Jacob gives her his copy of Donne's poems, whlch eventualiy lands on Sandra's bookshelf.

Strolling in at dusk, Sandra would open the books and her eyes would brighten (but not at the print), and subsiding Into the arm-chalr, she would suck back again the soul of the moment; or, for

40. P. 240-241.

41. P. 249 .

42. P. 270-271. 
sometlmes she was restless, would pull

out book after book and swing across

the whole space of her life like an

acrobat from bar to bar. She had had

her moments. Meanwhile, the great

clock on the landing ticked and Sandra

would hear time accumulating, and ask

herself, "What for? What for?"43

On Jacob's return from Greece, Bonamy promptly

guesses that Jacob is in love, and is angry because it is

not with Clara Durrant, whom Bonamy himself halfway loves.

As for Clara, she cannot forget Jacob, and is terribly

hurt because he does not come visit her. And poor Fanny

Elmer is totally desolate:

Sustained ent1rely upon picture post cards

for the past two months, Fanny's ldea of

Jacob was more statuesque, noble, and eye-

less than ever... "Plccadiliy?" Fanny asked

the conductor of the omnibus, and climbed to the top. After all, he would, he must, come back to her. But Jacob might have

been thinking of Rome; of architecture; of jurisprudence; as he sat under the plane tree in Hyde Park. 44

Then suddenly with only the vague warning from Betty

Flanders that "There was Morty 10st, and Seabrook dead;

her sons lighting for their country" 45 comes the last brief chaptẹr with the harshness of the reaction to Jacob's death in the war:

"He left everything just as it was," Bonamy marvelled. "Nothing arranged.

All his letters strewn about for any one

43. P. 275.

44. P. 291-292.

45. P. 300 . 
to read. What did he expect? Did he expect? Did he think he would come back?" he mused, standing in the midale of Jacob's room... Bonamy crossed to the window. Plckford's van swung down the street. The omnibuses were locked together at Mudie's corner. Engines throbbed, and carters, jamming the brakes down, pulled their horses sharp up. A harsh and unhappy volce crled something unintelligible. And then suddenly all the leaves seemed to ralse themselves. "Jacob! Jacob!" cried Bonamy, standing by the window. The leaves sank down again.

"Such confusion everywhere!" exclaimed Betty Flanders, bursting open the bedroom door. Bonamy turned away from the window. What am I to do with these, Mr. Bonamy?"

She held out a pair of Jacob's old shoes. 46

It $1 \mathrm{~s}$ repeatedly made clear that what $1 \mathrm{~s}$ of most Importance during this twenty-odd year period is not what Jacob is dolng so much as with whom he associates. Of special interest is his mother, Betty Flanders. Although Virginia Woolf in this book is quite impersonal towards her characters, the reader sympathizes with Betty in her welghty responsibility of ralsing a family alone, in her reaching out for friendship with Captain Barfoot, and especially in her rather pathetic attempts to keep in touch with Jacob through her letters. Jacob however, with indifference and thoughtlessness rather than any deliberate cruelty, has grown away from his mother's influence so that in his rooms after his death, it is

46. P. 302-303. 
his Irlend Bonamy rather than Betty who takes charge. Similarly the reader enters into Clara's gentle sadness, Florinda's yearning passion and Sandra's unexpressed, only half realized desires; yet it must be admitted that Jacob's reactions to all these are none too 1mpressive. For it is true that in Jacob's Room Virginia Woolf explores the consclousness of the minor characters much more intently than she does Jacob's, with the result that $1 J a c o b$ remains a nebulous young man, Indeed almost any young man, and the reader does not fully particlpate in the powerful effect he makes upon others. "47

There can be no doubt, however, that for creating an atmosphere, for 1mmortalizing a particular moment, and for setting forth the mutual impact of various personalities, Virginia Woolf in this book is developing a most effective and superior means of delineation.

47. Bennett, Joan, V1rg1n1a Woolf, p. 109. 
MRS. DALLOWAY

In Mrs. Dalloway Virginia Woolf has perfected the mode of expression she introduced in Jacob's Room. Although the basic technique remains, her characters are much more vivid, and her story is extremely well organized and effectively presented. Indeed I believe her art of casting an emotional spell over the reader reaches its helght in this book.

Mrs. Dalloway is not always so favorably interpreted, however. J. W. Beach seems to have escaped the impact of the book:

Like Ulysses, it is greatly taken up with the stream of consciousness of two or three characters, and has no plot. Like Ulysses, it introduces certain characters who have no connection with the leading persons, no bearing upon their fates. Septimus Warren Sm1th, crazed by his experience in the war, who finally kills himself to escape the oppression of the doctors, has nothing to do with Clarlssa Dalloway, the pensive soclal butterfly whose personality is most fully realized in the giving of parties. His fate and hers are simply complementary colors in the composition of this abstract painting, meant, it would seem, to give a certain impression of London life (or more universally stated, of Life 1tself.) I

One may guess that Virginia Woolf, in writing Mrs. Dalloway, had in mind, as her real subject, something like this: what

1. Beach, J. W., The Twentieth Century Nove1, p. 429. 
Iife seems like on a fine day in London.

Or perhaps more broadly, the sensation

of being alive. She must proceed from a center, and she has chosen for that a cultivated middle aged woman of fashion planning to give a party. Clarissa is a woman of some imagination, capable of straying rather far in fancy over the lighter aspects of Londion life. 2

Even David Dalches, admirer of Virginia Woolf that

he 1s, expresses some doubts:

The question for the critic is whether the process of rarification which goes on throughout the novel does not end by denuding 1t of a certain necessary vitality. 3

The present writer must confess that he received a considerable shock on first reading this (statement that Clarissa and Septimus are doubles; that at first Clarissa was meant to kill herself.) The casual remark about the part meant to be played by septimus seemed to be a refinement on the events described, so utterly unwarranted by the events themselves, and seemed to indicate so remote an attitude on the part of the author to the relation between fact and its interpretation, that for the moment the book ceased to have such meanling as it had possessed before and became a fantastic abstract allegory, which might mean anything and the refore meant nothing..... Is 1 t simply that the relation between the real and the symbolic aspects of the characters was not made sufficiently clear? or is it that the symbolic aspects are out of proportion to the real aspects? Perhaps the latter question gets nearer the truth. The refining intellect seems to have "O'erleapt itself and fallen on the other side." 4

2. Ibid., p. 431.

3. Dalches, David, op. c1t., p. 77.

4. Dalches, David, The Novel and the Modern World, p. 181. 
The comments of these two critics concerning Mrs. Dalloway seem to display some lack of insight. In stressing the "1mpression of London life," the vagueness of character connections, the technique used and the lyrical quality of the prose, they have slighted the implications of the story 1 tself and the subtle relationships of its characters.

Mrs. Dalloway is the story of one day in a middle aged woman's life, but not just any day chosen at random. It 18 a day of crisis. For various reasons, Clarissa Dalloway feels that although she has recovered from her illness, she is now of little use to the world. The party which she gives that night is an effort to prove that she is worthwhile; that there is some reason for her continued existence. This feeling is reflected in the atmosphere of urgency, of the nearness of old age and of death which permeates the pages of the book. Clarissa is a woman 51 years old who has just recovered from a serlous illness. She is referred to as "grown very white since her 1liness," 5 and later, the fact is mentioned that "since her IIIness she had turned almost white." 6 Again, "That might be her heart, affected, they said, by influenza. "? She thinks of the

5. Woolf, Virginia, Mrg. Dalloway, P. 4

6. P. 54.

?. P. 4. 
hatred, which "especially since her 1llness, had power to make her feel scraped, hurt in her spine. "8 In describing her virginal looking bedroom, it is mentioned that her husband Richard "Insisted, after her 1llness, that she must sleep undisturbed." 9 Finally, Peter, who loved her, thinks, "She has been 111, and the sound of the clock striking expressed languor and suffering. It was her heart, he rememberea. "10

Having recovered from this lliness, Mrs. Dalloway seems pursued by a dread of middle age, of old age and of eventual death. Vitality has always seemed so important to her. Peter, thinking of her, says, "And of course she enjoyed life immensely. It was her nature to enjoy."ll We see her "loving it [1ife] as she did with an absurd and falthful passion, being part of it." 12 She herself says "What she liked was simply life."13 Later, "How unbellevable death was! that it must end; no one in the whole world would know how she had loved 1t al1." 14

At the same time, the thoughts of age keep intrud1ng: "She felt very young, at the same time unspeakably

8. P. 17 .

9. P. 46.

10. P. 75 .

11. P. 118.

12. P. 6 .

13. P. 183.

14. P. 185. 
aged." 15 As she thinks that "what she loved was this, here, now, in front of her; the fat lady in the cab," she begins to think that she must eventually cease completely, that "all this must go on without her." 16 She is shocked by the fact that Peter, older than she, can be in love. "He's $81 x$ months older than I am!... In her heart she felt, all the same, he's in love. He has that, she felt; he is in love... He was in love! Not with her. With some younger woman, of course." 17 Peter thinks of her "whereas it was this; it was midale age; It was mediocrity." 18

Death repeatedly enters her thoughts. "She had a sudden spasm, as if, while she mused, the loy claws had had the chance to $11 x$ in her." And then, reassuringly, she thinks, "She was not old yet. She had just broken into her fifty second year. Months and months of $1 \mathrm{t}$ were st1ll untouched. "19 Peter, thinking of her 1liness, has a sudden vision of "death that surprised in the midst of life, Clarissa falling where she stood in her drawing room. No! No! he cried. She is not dead! "20 Later on,

15. P. 11.

16. P. 12.

17. P. 17.

18. P. 236 .

19. P. 54 .

20. P. 75. 
he muses on her "horror of death." 21 At the party, the vigorous laughter, "as she heard it across the room, seemed to reassure her on a point which sometimes bothered her if she woke early in the morning and did not like to call her mald for a cup of tea; how it is certain we must die." 22 The news of the death of young Septimus Smlth has a disturbing effect upon Clarissa, which will be discussed in detall later.

Another factor that adds to Clarissa's feeling of being unnecessary and mladle aged is the fact that Lady Bruton Invites Richard to luncheon and does not include her. "'Dear!' sald Clarissa and Lucy shared as she meant her to her disappointment (but not the pang)." 23

Fear no more, sald Clarissa. Fear no more the heat of the sun; for the shock of Lady Bruton asking Richard to lunch without her made the moment in whlch she stood shiver, as a plant on the river bed feels the shock of a passing oar and shivers; so she rocked; so she shivered..... She feared time 1tself, and read on Lady Bruton's face, as if it had been a dial cut on impassive stone, the dwindling of Ilfe; how year by year her share was sliced; how little the margin that remained was capable any longer of stretching, of absorbing, as in the youthful years, the colors, salts, tones of exlstence..... 24 feeling herself suddenly

21. P. 231.

22. P. 267.

23. P. 43 .

24. P. 44. 
shrivelled, aged, breastless, since Lady Bruton, whose lunch partles were sald to be extraordinarily amusing, had not asked her. 25

These very same words are repeated in her mind that afternoon: "and Lady Bruton, whose lunch partles were said to be extraordinarily amusing, had not asked her." 26 Clarissa's married life has reached a point where she feels rather unnecessary even there. Peter, thinking of the first time he saw her and Richard together, had a sudden feeling that they would marry. "There was a sort of - how could he put 1t? - a sort of ease in her manner to him; something maternal; something gentle. "27 Th1s feeling instead of a passionate love is the basis of Clarissa's and Richard's attachment.

Although Richard is quite devoted to her in a rather calm, gentle way, she feels she has gone back almost to a virginal state.

Ready to rest in the morning, like a nun withdrawing, or a child exploring a tower, she went upstairs... There was an empt1ness about the heart of life; an attic room... The sheets were clean, t1ght stretched in a broad white band from side to side. Narrower and narrower would her bed be. The candle was half burnt down and she had read deep in Baron Marbot's Memoirs. She had read late at night of the retreat from Moscow. For the House

$$
\begin{array}{ll}
25 . & \text { P. } 45 . \\
26 . & \text { P. } 178 \\
27 . & \text { P. } 93
\end{array}
$$


sat so long that Richard insisted, after her 1llness, that she must sleep undisturbed. And really she preferred to read of the retreat from Moscow. He knew 1 t. So the room was an att1c; the bed narrow and lying there reading, for she slept badly, she could not dispel a virginity preserved through chlldbirth whlch clung to her like a sheet. 28

She goes on thinking that she has always lacked something in her contact with Richard, that in some way she has falled him.

It was something central which permeated (which she lacked); something warm which broke up, surfaced and rippled the cold contact of man and woman, or of women together. For that she could dimly percelve... she could not resist sometimes ylelding to the charm of a woman... Against such moments (w1th women, too) there contrasted (as she lald her hat down) the bed and Baron Marbot and the candle half burnt. Lying awake, the floor creaked; the lit house was suddenly darkened, and if she ralsed her head she could just hear the click of the handle released as gently as possible by Richard, who slipped upstairs in his socks and then, as often as not, dropped h1s hot water bottle and swore! How she laughed! 29

Then, with the implication that love is something else, she goes on thinking "But this question of love... "30

Clarissa feels the need for justifying, if possible, her marriage. She keeps wondering if she should have married Peter, if it would have been falrer to all of

\begin{tabular}{lll}
\hline 28. & P. & 46 \\
29. & P. & 47 \\
30. & P. & 48
\end{tabular}


them if she had.

So she would still find herself arguing in St. James Park, st1ll making out that she had been right - and she had too - not to marry him. For in marriage a little license, a little independence there must be between people living day in day out in the same house; which Richard gave her and she him. 31

When Peter comes to see her, she thlnks, "Now of course he's enchanting, perfectly enchanting! Now I remember how Impossible it was ever to make up my mind and why did I make up my mind - not to marry him? she wondered, that awful summer.... 32 Th1s is what I have made of 1t! [11fe] What had she made of 1t? What indeed? sitting there sewing this morning with Peter." 33 "She sat back extraordinarily at her ease with him and light hearted, all in a clap it came over her, if I had marrled hlm this galety would have been mine all day! 34 Then, with a sense of the emptiness of what she has Instead,

It was over for her. The sheet was stretched and the bed narrow. Richard, Richard! she oried, as a sleeper in the night starts and stretches $a$ hand in the dark for help - Lunching w1 th Lady Bruton, it came back to her. He has left me; I am alone forever, she thought, folding her hands upon her knee. 35

$\begin{array}{lll}31 . & \text { P. } 10 . \\ 32 . & \text { P. } 62 . \\ 33 . & \text { P. } 64 . \\ 34 . & \text { P. } 70 . \\ 35 . & \text { P. } 70 .\end{array}$ 
Richard "had, once upon a time, been jealous of Peter Walsh; Jealous of him and Clarissa. But she had often sald to him that she had been right not to marry Peter Walsh; whlch, knowing Clar1ssa, was obviously true; she wanted support. Not that she was weak; but she wanted support. "36 As he leaves her in the afternoon, he wonders, "D1d she wish she had married Peter? "3?

It is impossible to keep from liking Rlchard. Considerate, gentle, agreeable, he feels a deep affection for Clarlssa, very little troubled by the doubts which assall her. At Lady Bruton's luncheon, he suddenly wants to get home to Clarissa to tell her that he loves her. He goes with the pompous Hugh Wh1tbread who is buying a necklace for his wife Evelyn and thinks he would like to take a present to Clar1ssa, yet doubts his taste, since once he bought her a bracelet which she never wore. He decides to take flowers and thinks he w1ll walk in, give her the flowers and say "I love you." He wonders why it is that one never speaks of love. "And they never spoke of 1t; not for years had they spoken of 1t; which, he thought, is the greatest mistake in the world. The time comes when it can't be

36. P. 177 .

37. P. 181 . 
said, one's too shy to say 1t, he thought." 38 And sure enough, after giving her the flowers, "he could not bring himself to say he loved her; not in so many words. But how lovely, she sald, taking his flowers. She understood; she understood without his speaking; his Clarissa." 39 But he could not tell her he loved her. He held her hand. Happiness is this, he thought. "40 As he leaves Clarissa, he wants her to take her dally rest. She thinks,

How like him! He would go on saying "an hour's complete rest after luncheon" to the end of time, because a doctor had ordered 1t once. It was like him to take what doctors sald 11terally; part of his adorable, divine simplicity, which no one had to the same extent; which made him go and do the thing while she and Peter frittered their time away bickering. 41

Clarissa seems to love Rlchard in a tolerant, sweet sort of way, yet she allies herself with Peter.

There is a deep affection between Richard and his daughter Ellzabeth. On his way home from the luncheon the thought comes to his mind, "But he had his Elizabeth; he adored his Elizabeth. 42 That night at the party, sally says "One can see they are devoted to each other. 
She could feel it by the way Elizabeth went to her father. ${ }^{43}$
"For her father had been looking at her, as he stood talking to the Bradshaws, and he had thought to himself, who is that lovely girl? And suddenly he realized that $1 t$ was his Ellzabeth and he had not recognlzed her, she looked so lovely in her pink frock!...... And Richard and Ellzabeth were rather glad 1t was over [the party, but Richard was proud of his daughter. And he had not meant to tell her so, but he could not help telling her. He had looked at her, he sald, and he had wondered, who is that lovely girl? and it was his daughter! That did make her happy. But her poor dog was howling. " 44

Peter and Sally, both rather intellectually snobbish and brilliant, yet often undependable, are characteristic in their feelings towards Richard. Pter thinks: "He was a thorough good sort; a b1t Iimlted; a bit thick in the head; yes; but a thorough good sort. Whatever he took up he did in the same matter-of-fact sensible way; without a touch of Imagination, without a spark of brilliancy, but with the Inexplicable niceness of his type. He ought to have been a country gentleman - he was wasted on politics. He was best out of doors, w1th horses and dogs." 45 His feeling toward Richard coinclded with Sally's. He thinks

$$
\begin{array}{ll}
\text { 43. P. 295. } \\
\text { 44. P. 295-296. } \\
\text { 45. P. 113. }
\end{array}
$$


how Sally used to beg him "to carry off Clarissa, to save her from the Hughs and Dalloways and all the other 'perfect gentlemen' who would 'stifle her soul'... make a mere hostess of her, encourage her worlaliness. " 46 After all these years, Sally, still critical at the party again asks Peter, "how could Clarissa have done 1t? married Richard Dalloway? A sportsman, a man who cared only for dogs. Literally, when he came into the room he smelt of the stables.... ${ }^{47}$ And Clarlssa had cared more for him [Peter] than she had ever cared for Richard. Sally was positive of that. No, no, no, said Peter. (Sally should not have said that - she went too far). That good fellow - there he was at the end of the room holding forth, the same as ever, dear old Richard. "48

There is little of this calmness, this gentleness between Clarissa and Peter. Their relationship seems to have been temptestuous and flery, full of extremes of joy or anger, so unsettled in fact that Clarissa chose Richard Instead. Peter enters Clarlssa's thought constantly. The very flne morning makes her think "he could be intolerable; he could be impossible; but adorable to walk with on a morning like this. "49 His

46. P. 114.
47.
P. 288.
49.
P. 293.
P. 8.


possessiveness overcame her.

"But with Peter everything had to be shared; everything gone into. And 1t was intolerable and when it came to that scene in the ilttle garden by the fountain, she had to break with him or they would have been destroyed, both of them ruined, she was convinced; though she had borne about with her for years like an arrow stlcking in her heart the grief, the anguish. "50

Peter too now realizes that his early impetuosity had been too much. "For himself, he was absurd. He asked Impossible things. He made terrible scenes. She would have accepted him still, perhaps, if he had been less absurd. "51

After Peter was refused by Clarissa, he had left for India, and soon married some woman he met on the boat, the marriage not turning out happlly although the Inal outcome is not gone into. In the interval between these years and the present, he had done little. Lady Bruton, seeing him at the party, thinks of him as "that agreeable sinner, that very able fellow who should have made a name for himself but hadn't (always in difficulty with women). "52 He has returned to England to arrange for the divorce of Daisy, wife of a major in the Indian army, mother of two small children, whom he intends to

50. P. 10.

51. P. 75.

52. P. 273. 
marry.

Yet when he tells Clarlssa of his approachtng marriage, the news falls somewhat plat. "And then, to his utter surprise, suddenly thrown by those uncontrollable forces thrown through the alr, he burst into tears; wept; wept w1thout the least shame." 53 Afterwards, of course, he is "overcome with shame suddenly at having been a fool." 54 He seems unable to escape from his old feeling for Clarissa. He stands there on the street, "feeling hollowed out, utterly empty within. Clarissa refused me, he thought. He stood there thinking clarissa refused me." 55

He cannot help contrasting his present feeling for Daisy with his passionate attachment for Clarissa. "It was impossible that he should ever suffer again as Clarissa had made him suffer. For hours at a time, for hours and days he never thought of Dalsy. Could it be that he was in love with her then?" 56 He comes to the conolusion that perhaps it is because this time Daisy is in love with him. He realizes that it is really a relief to be away from her; "One doesn't want people after flety; one doesn't want to go on telling women they

53. P. 69.

54. P. 73.

55. P. 74 .

56. P. 120. 
are pretty. 157 He even goes so far as to think that "all this pother of coming to England and seeing lawyers wasn't to marry her, but to prevent her from marrying anybody else." 58 Later in the day, thinking more about the proposed future, he comes to the conclusion that "Well, Indeed, he had got himself into a mess at his age...59 In short it might be happler, as Mrs. Burgess sald, that she should forget him. "60 At the party he admitted to Sally that "One could not be in love twice." 61

Peter's love for Clarlssa does not keep him from seeing and oriticizing her faults. He is irritated w1th her mending her dress, placing so much 1mportance on a party, her hiatrionic manner of introducing Elizabeth annoys him. He feels "there was always something cold in Clarissa... 62 Clarissa was as cold as an 1c1cle." 63 "She had always, even as a girl, a sort of timldity, which in middle age beomes conventionality, and then 1t's all up, 1t's all up." 64 Even in the days at Bourton "1t was her manner that annoyed h1m; tim1d;

57. P. 120.

58. P. 121 .

59. P. 238 .

60. P. 240 .

61. P. 292.

62. P. 73.

63. P. 122.

64. P. 73. 
hard; something arrogant, unimaginative, prudish... the death of her goul. 65

Nevertheless, he clings to her as to an ideal.

He always felt that her refusing to marry him was the turning point in his life, that it was the ruin of his 11fe. And now he cannot separate himself from her.

"But 1t was Clarissa one remembered. Not that she was striking, not beautiful at all; there was nothing picturesque about her; she never sald anything especlally clever; there she was, however, there she was. No, No, No! He was not in love with her any more! He only felt... unable to get away from the thought of her." 66

He thinks back over the years they have been separated.

Brief, broken, often painful as their actual meetings had been what with his absences and interruptions..... the effect of them on his life was immeasurable. There was a mystery about $1 \mathrm{t.....}$ She had influenced him more than any person he had ever known. 67

That night, at the party, he is tremendously anxious to talk to her, yet glimpses are all he can get. She brings Aunt Helena to talk to him "And yet he had not had a word with her all the evening!"68 sitting talking to sally seton, Peter is restless. "But where 18 Clarissa? sald Peter. Where's the woman gone to? he

65. P. 89.

66. P. 115 .

67. P. 232.

68. P. 272 . 
- asked. Where's Clarisap"69 Sally sees this restlessness: "Poor Peter, thought Sally, why did not Clarissa come and talk to them? That was what he was longing for. She knew 1t. All the time he was thinking only of Clarissa and was fidgeting with his knife." 70

H1s feeling of suspense and excitement is extremely well expressed in the concluding paragraph of the book, as Sally gets up to speak to Richard:

"I w11l come," said Peter, but he sat on for a moment. What is this terror? What 18 this ecstasy? he thought to himself. What is 1 that filis me with extraordinary excitement? It is Clarissa, he sald. For there ghe was. 71

Clarisga's daughter Elizabeth is a strong source of dissatisfaction to her. seeing them together for the first time in several years, Peter thinks, "Probably she doesn't get on with Clarlssa." 72 At the present, Clarissa is very much worried because of Elizabeth's preoccupation with the unattractive, fanatical Doris Kilman. For hours, to Clarissa's disgust, Elizabeth and Misg Kilman have been shut up together, probably praying. Mrs. Dalloway has the feeling that Elizabeth no longer needs her, that Miss Kilman has taken her away. Although despising her,

69. P. 284 .

70. P. 292.

71. P. 296.

72. P. 84 . 
Clarissa envies her slightly because of this. "This woman had taken her daughter from her! she in touch with invisable presences! Heavy, ugly, commonplace, w1thout kindness or grace, she knew the meaning of I1fe! $n^{73}$ At the party she again thinks of M1ss Kilman: "Kilman - her enemy. That was sat1sfying; that was real; ah, how she hated her - hot, hypocritical, corrupt; with all that power; Ellzabeth's seducer - the woman who had crept in to steal and defile (Richard would say, what nonsense!) " 74

Yet the fact is that Miss K1lman has not stolen Elizabeth. Already Ellzabeth is growing away from her influence, in splte of Miss Kilman's desperate efforts to hold on to her. As they sip tea together, Miss Kilman is agonized when Elizabeth, slightly bored, begins to leave:

"Ah, but she must not go!

Miss Kilman could not let her go.

This youth, that was so beautiful, this girl, whom she genuinely loved!... She was about to spilt asunder, she felt. The agony was so terrific. If she could grasp her, if she could clasp her, if she could make her hers absolutely and forever and then die; that was all she wanted. But to sit here, unable to think of anything to say, to see Elizabeth turning against her, to be felt repulsive even by

73. P. 190.

74. P. 265-266. 
her - it was too much; she could not stand 1t...p.200. Like some dumb creature who has been brought up to a gate for an unknown purpose, and stands there longling to gallop away, Ellzabeth Dalloway sat silent... gone. Beauty had gone, youth had gone. 175

Ellzabeth is pletured as a rather attractive, quiet, thoughtful girl.

"People were beginning to compare her to poplar trees, early dawn, hyacinths, fawns, running water and garden lilies; and $1 t$ made life a burden to her, for she much preferred beling left alone to do what she $11 \mathrm{ked}$, in the country, but they would compare her to lilies, and she had to go to parties, and London was so dreary compared with being alone in the country with her father and the dogs."176

"Her interest in people who are sick, in the country, in animals, makes her quite determined, whatever her mother might say, to become elther a farmer or a doctor."77 Walking around through Fleet street, "a ploneer, a stray, venturing, trusting, "78 she finds it was "later than she thought. Her mother would not like her to be wandering off alone like this. She turned back down the Strand... Calmly and competently, Elizabeth Dalloway mounted the Westminster omnibus. "79

$\begin{array}{lll}75 . & \text { P. } 201 . \\ 76 . & \text { P. } 204 . \\ 77 . & \text { P. } 207 . \\ 78 . & \text { P. } 208 . \\ 79 . & \text { P. } 211 .\end{array}$


No one seems to understand how Clarissa feels about her party. Although Richard is willing for her to give parties $1 f$ she wishes, "It was a very odd thing how much Clarissa minded about her parties, he thought... If she worrled about these parties he would not let her give them. 180 Peter 1s even more critical of them. "Here she's been sitting all the time I've been In India; mending her dress; playing about; going to partles; running to the House and back and all that, he thought growing more and more irritated, more and more agitated... ${ }^{81}$ Oh these parties, he thought; Clarissa's parties. Why does she give these parties, he thought. "82

Clarissa is quite sensitive to this criticism.

"But, why did she suddenly feel, for no reason that she could discover, desparately unhappy?... It was a feeling, some unpleasant feeling, earlier in the day perhaps; something that Peter had sald, combined with some depression of her own... And what Richard had sald had added to it, but what had he sald? Her parties! That was 1t! Her parties! Both of them criticised her very unfalrly, laughed at her very unjustly, for her parties. That was 1t! That was $1 \mathrm{t!}$ " 83

Clarissa realizes that concerning parties Peter

80. P. 180.

81. P. 61 .

82. P. 72.

83. P. 183. 
thinks her quite snobblsh and Richard thinks her childish.

And both were wrong, what she $11 \mathrm{ked}$ was simply life. "That's what I do it for," she sald, speaking aloud, to 11 fe..... What did 1 t mean to her, the thing she called life? oh, it was very queer. Here was so-and-so in South Kensington; someone up in Mayswater; and somebody else, say, in Mayfair. And she felt quite continuously a sense of their existence; and she felt what a waste; and she felt what a pity; and she felt if only they could be brought together; so she did 1t. And 1t was an offering to combine, to create, but to whom? An offering for the sake of offering, perhaps. Anyhow, it was her gift. Nothing else had she of the silghtest Importance; could not think, write, even play the plano. 84

So she feels that parties are the only contribution that she can make to life; the only justification of her existence. And the party tonight seems especially Important to her, as though to prove that in spite of her 1liness, in splte of Elizabeth's drifting away from her, In spite of approaching old age she still has an 1mportant offering to make. She hopes to hold to those she loves by these parties. Peter, thinking of Clarissa and Rlchard, says "These parties for example were all for him or for her 1dea of him (to do Richard justice he would have been happler farming in Norfolk)." 85 As

84. P. 185.

85. P. 116. 
Peter leaves her in the morning, w1 thout looking at her, leaving the room quickly, 86 "Peter, she calls after hlm: Peter,' crled Clarlssa, following him out on to the landing, 'My party tonight! Remember my party tonight!' sounded very frall and thin as Peter Walsh shut the door. "8?

Under somewhat similar clrcumstances, when Elizabeth and Miss K1lman leave the house together, "W1th a sudden impulse, with a violent anguish, for this woman was taking her daughter from her, Clarissa leant over the bannisters and crled out, 'Remember the party! Remember our party tonight!' But Elizabeth had already opened the front door - there was a van passing; she did not answer. " 88

That night Clarissa is not completely satisfied, although the party seems to be successful.

And yet for her own part, it was too much of an effort. She was not enjoying 1t. It was too much like belng - just anybody, standing there; anybody could do 1t; yet this anybody she did a little admire. Couldn't help feeling that she had anyway, made th1s happen.....89 she had felt that intoxication of the moment, that dilatation of the nerves of the heart itself till it seemed to quiver, steeped upright; - yes, but after all, 1t was what other people lelt, that;
86. P. 71.
87. P. 72.
88. P. 191.
89. P. 259. 
for, though she loved it and felt it tingle and sting, still these semblances, these triumphs had a hollowness; at arm's length they were, not in the heart; and it might be that she was growing old but they satigfied her no longer as they used. 90

In a way, then, her parties, the one thing upon which Clarissa felt she could depend, have falled her.

The tragic story of Septimus Warren Smith 1 s woven through the novel. He is seen, as is Clarissa, looking at the royal car and the alrplane; he is seen by Peter In the park; and he 18 seen in contact with Dr. Bradshaw and later Dr. Holmes. He is a young ldealist who volunteered and served with distinction in the World War, whose mind has been terribly affected by it and especially by the death of his friend Evans. While in Italy, he had been overcome by "sudden thunderclaps of fear; he could not feel." 91 While visiting a gay Italian family, he became engaged one evening when the panic was on him - that he could not feel." 92 He and h1s pretty young wife, Rezla, came back to London, and steadiy his condition became worse. He has revelations concerning death and 11fe, concerning love and hate, and he sees the dead Evans frequently. Septimus feels that human nature has condemned him for his crime of

90. P. 265 .

91. P. 131.

92. P. 131 . 
being unable to feel anything, and that "it must be the fault of the world, then - that he could not feel. " 93

Most potent of all is his conviction that the world is agalnst him. "For the truth is that human belngs have neither kindness, nor faith, nor charity beyond what seems to increase the pleasure of the moment. They hunt in packs....994 Human nature, in short, was in him - the repulsive brute, with the blood red nostrils. Holmes was on him. Once you stumble, Septimus wrote on the back of a postcard, human nature is on you. "95 To him, human nature is personified in Dr. Holmes and S1r William Bradshaw. "Once you fall, Septimus repeated to himself, human nature is on you. Holmes and Bradshaw are on you. They scour the desert. They fly screaming into the wllderness. The rack and the thumbscrew are applied. Human nature 18 remorseless." 96

Although Sept1mus feels that death is the penalty demanded of him by human nature, he does not wish to die. "The whole world is clamouring, kill yourself, kill yourself for oursakes. But why should he kill himself for their sakes?"97 "But if he confessed? If

93. P. 133.

94. P. 135.

95. P. 139.

96. P. 148.

97. P. 140 . 
he communicated? Would they let him off then, his torturers?" 98

For a while in the afternoon he is happy, at peace unt1l Holmes forces his way into the room. "Holmes would get him. But no, not Holmes, not Bradshaw... But he would walt t1ll the very last moment. He did not want to die. Life was good. The sun hot. Only human belngs - what did they want?" 99 And so, "he flung himself out the window, violently down onto Mrs. Filmer's area rallings. "100

The Pirst knowledge that Clarissa has of Septimus is at the party, when S1r Willam Bradshaw tells of the sulcide of one of his patients, a young man who had been in the army, and mentions something about the deferred effects of shellshock. The news has a strong effect upon Clarissa. There seems to be a kinship between the two of them, suggested by various phrases through the book. Both have the same feeling of belng alone, of being deserted. Clarissa, reallzing that she does not have Peter and that Richard is with Lady Bruton thinks "I am alone forever, "IOI and Septimus, starting up in terror, not seelng Rezia, thinks "That

98. P. 148 .

99. P. 226. 100. P. 226. 101. P. 70. 
was 1t: to be alone forever. That was the doom pronounced in Milan when he came into the room and saw them cutting out buckram shapes with their scissors; to be alone forever. " 102

Both are strongly affected by fear. "Fear no more," sald Clarissa. Fear no more the heat of the sun...but she feared time 1tself... 103 Then (she had felt it only this morning) there was the terror there was in the depths of her heart an awful fear. "104 And Septimus, "now that it was all over, truce signed, and the dead burled, had especially in the evening, these sudden thunderclaps of fear... ${ }^{105}$ Fear no more, says the heart in the body; fear no more... 106 But then, he started up in terror. "10?

Clarissa feels a kinship with the way Septimus must have reacted to sir william.

She did not know what it was about Sir Wflliam; what exactly she disliked .....1080r there were the poets and thinkers. Suppose he (Septimus) had had that passion, and had gone to Sir William Bradshaw, a great doctor yet to her obscurely evil, without sex or lust, extremely pollte to women, but capable of some indescribable outrage forcing your soul, that was it - $1 f$

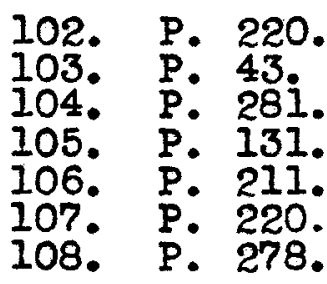


this young man had gone to $\mathrm{h} 1 \mathrm{~m}$, and Sir William had impressed him, like that, with his power, might he not then have said (indeed she felt it now) life is made intolerable; they make I1fe intolerable, men like that? 109

The news of his death makes her feel drawn towards him. She 1magines how he must have felt, throwing himself from the window, hitting the splkes. She herself "had once thrown a shilling into the serpentine, never anything more. But he had flung it away. "110 She realizes that she will go on living, becoming old, and feels that by his dying young he had preserved something, for "Death was deflance. Death was an attempt to communicate;... there was an embrace in death. "111

Then she herself is really afraid of life, of the responsibility of having one's life to live to the end. "Even now, quite often $1 f$ Richard had not been there reading the rimeg so that she could crouch like a bird and gradually revive... she must have perlshed. But that young man had killed himgelf."1l2 And as Delattre suggests, "Qui sait meme s1, a l'exemple du paurre maniaque, la grande dame, dans la terreur veritable

109. P. 281.

110. P. 280.

111. P. 20 .

112. P. 282. 
qui l'obsede, n'ira pas, elle auss1, jusqu'au sulc1depnll3

She even feels gullty that he should have died wh1le she still 11ves. "Somehow it was her disaster her disgrace. It was her punishment to see sink and disappear here a man, in this profound darkness, and she forced to stand here in her evening dress. "114 As she stands there in her room, she sees the old lady in the room opposite pulling down the blind, going to bed, symbollc of the end of the day and of the end of 1110.

It was fascinating, with people still laughing and shouting in the drawing room, to watch that old woman, quite quietly, going to bed..... The young man had killed himself; but she did not pity him..... There! the old lady had put out the 1ight! The whole house was dark now with this going on, she repeated, and the words came to her. Fear no more the heat of the sun. 115

The death of Septimus seems to take away any immediate thought of her own death.

She must go back to them. But what an extraordinary night! She felt somehow very like him - the young man who had killed himself. She felt glad that he had done 1t; thrown it away...... He made her feel the beauty, made her fell the fun. But she must go back. 116

113. Delattre, Flor1s, Le Roman Psychologique de V1rginia Woolf., p. 97 .

114. Wolf, VIrginia, Mrs. Dalloway, p. 282.

115. P. 283.

116. P. 283-284. 
The technique and method of Mrs. Dalloway which have been the center of so much attention surely are not as important as Daiches for example considered them. Virginia Woolf herself received the criticism that the book was the "deliberate offspring of a method." 117 and she herself also says that "the facts are otherw1se... The book grew day by day, week by week, without any plan at all except that whlch was dictated each morning in the act of writing... In the present case it was necessary to write the book first and to invent a theory afterwards. "118

As the novel is mainly confined to one woman's mind, and as the other characters are shown in relation to her, it seems $\log 10 a l$ to confine the action of the book to the passage of one day, espectally since the day is one of crisis in Clarissa Dalloway's life. Thus, 8.side from the technical perfection, the 1dea of the novel also fits the method chosen.

The end of the day and of the book does not, however, finally solve the problems of the characters. Peter still hopelessly yearns for Clarissa, and one is not at all sure that Clarissa has regained from the party the necessary vitality to continue her existence,

117. P. V11.

118. P. V111. 
In spite of her feeling that Septimus has removed any thought of her Immediate death. Her quality for knowing people, her preoccupation with life and death, her strong kinship w1th the tragic Septimus, and even this unsettled state of mind at the end of the book, surely make her a living character and not simply the "woman of some imagination, capable of straying rather far in fancy over the l1ghter aspects of London l1fe." 


\section{TO THE LIGHTHOUSE}

Virginia woolf malntains her unique literary charm and narrative achievement in To The Lighthouge. A flavor of whimsical humor, a rather tender understanding of children along with a vivid emotional depth, and most signally perhaps, a consuming interest in the various phases of human relationshtps, all in varying degrees are inherent in the last of this selected $\operatorname{tr1logy.}$

The scene of this story is rather far removed from the bustle of London which pervades Mrs. Dalloway; To The Lighthouse has its origin on the coast in Scotland, where the summer home of the Ramsays is located: "The chlldren loved 1t; it did her husband good to be three thousand, or if she must be accurate, three hundred miles from his libraries and his lectures and his disciples; and there was room for visitors."I Virginia Woolf seems purposely to have avolded detalls concerning the location, so much so that the outside world, even the nearby town, is unreal; this was rather unimportant to the Ramsay home, and thus it seems 1solated as it

1. Woolf, V1rginia, To The Lighthouse, p. 43. 
faces "the great plateful of blue water" w1th the "hoary Lighthouse, distant, austere, in the midst; and on the right, as far as the eye could see, fading and falling, in soft low pleats, the green sand dunes with the wlld flowing grasses on them, which always seemed to be running away into some moon country, uninhabited of men. ${ }^{2}$

The book is divided into three general sections, the first covering speciflcally the events of one day In the lives of Professor and Mrs. Ramsay, their elght chlidren and their visitors. To the delight of six year old James, the Ramsays are planning a trip to the Lighthouse the next day to take "whatever comforts one $\operatorname{can}^{3}$ to the keeper and his family; Minta Doyle and Paul Raylay, two young visitors, become engaged; Charles Tansley, the awkwardly pathetic "little atheist", succeeds in Irritating everyone; Mrs. Ramsay definitely decides that Willam Bankes and Lily Briscoe, the artist, who is working on a portrait of Mrs. Ramsay, should marry since they have so much in common - "they are both cold and aloof and rather self-sufficing; "4 the rude old poet, Augustus Carmichael, eats too much soup at

$$
\begin{array}{ll}
\text { 2. } & \text { P. } 23 . \\
\text { 3. } & \text { P. } 12 . \\
\text { 4. } & \text { P. } 157 .
\end{array}
$$


dinner; and $\mathrm{Mr}$. Ramsay, after angrily predicting that bad weather w1ll prevent the planned trip, mutely apologizes and recelves sympathy and comfort from Mrs. Ramsay.

In her lyrical fashion, Virginia Woolf in the next and shortest section sweeps over the following ten years, with only occasional references to the family. Highly lmaglnative and emotional passages describe the passing of the nights, of the seasons, and of the years, during which time the house gradually molds and decays. Tucked into these passages are the cold and simply stated facts of Prue's marrlage and death in childbirth, of Andrew's death in the war, and of Mrs. Ramsay's death. Finally the cleaning women step in just in time to rescue the house from total decay in preparation for the return of Mr. Ramsay.

The third chapter again brings together Mr. Ramsay, two of the children, and Llly Briscoe and Augustus Carmichael, all of whom were present ten years before. The long postponed journey to the Lighthouse is finally made by Mr. Ramsay, Cam, and James; and James has never quite forgotten his father's seeming delight in shattering his joy in that prospective trip of ten years before. As they reach the Lighthouse, however, his antagonism melts away and he feels sympathy and affection for his 
father. Lily Briscoe, again a visitor at the long neglected home, has found the unfinished portralt of Mrs. Ramsay, which she completes, but only after reaching the conclusion that she and old Mr. Carmichael have sllently reached an important understanding.

All the relationships between the various characters, their responses and reactions to each other and their varlous philosophles of life are elaborated within a remarkable simple plot-framework; $\mathrm{Mr}$. and Mrs. Ramsay, the central characters, fulfill a basic need in each other. She assumes the role of comforter for him, so that when he comes to her, needing sympathy, feeling himself a fallure, she

seemed to ralse herself w1th an effort and at once to pour erect into the air a rain of energy, a column of spray, looking at the same time animated and alive as if all her energies were being fused into force, burning 1lluminating (quietly though she sat, taking up her stocking again) and into this delicious fecundity, this fountain and spray of 11fe, the fatal sterility of the male plunged 1tself, like a beak of brass, barren and bare... She assured him, beyond a shadow of a doubt, by her laugh, her polse, her competence (as a nurse carrying a light across a dark room assures a fractious child) that it was real; the house was fuli, the garden blowing. If he put implicit falth in her, nothing should hurt him; however deep he burled himself or climbed high, not for a second should he find himself without her. So 


\section{boasting of her capacity to surround and protect there was scarcely a shell of herself left for her to know herself by..... Filled with her words, like a child who drops off satisfied, he said, at last, looking at her with humble gratitude, restored, renewed, that he would take a turn..... Immediately Mrs. Ramsay seemed to fold herself together, one petal closed in another, and the whole fabric fell in exhaustion upon itself. 5}

This soothing extends not only to her husband, but to hosts of other men, for "Indeed she had the whole of the other sex under her protection, for reasons she could not explain, for their chivalry and valour, for the fact that they negotiated treaties, ruled India, controlled finance; finally for an att1tude towards herself which no woman could fall to find agreeable, something trustful, chilalike, reverential. "6 so when she sees Charles Tansley "standing by the table, fidgeting with something awkwardly, feeling himself out of things, ${ }^{7}$ she kindly asks him to go to town with her, reviving his spirits by her beauty and her gracious charm.

At times Mrs. Ramsay herself doubts her motives, for when Mr. Carmichael Ignores her gestures of friendship, she is hurt; she misses the admiration which is

5. P. 58-60.

6. P. 13.

7. P. 18 
usually hers.

Was it not secretly this that she wanted, and therefore when Mr. Carmichael shrank away from her, as he did at this moment, making off to some corner where he did acrostics endlessly, she did not feel merely snubbed back in her instinct, but made aware of the pettiness in some part of her, and of human relations, how llawed they are, how desplcgble, how self seeking at their best.

She does however seem to find her satisfaction in working with and for others, in organizing and in arranging. It was her idea that Paul and Minta should marry; and watching her at the dinner table, Lily Briscoe sees "something Irightening about her. She was largely irresistible. Always she got her own way in the end, Lily thought. Now she had brought this off. Paul and Minta, one might suppose, were engaged." 9 The Idea that W1Iliam and Lily also should marry occurs to Mrs. Ramsay, and she 1mmediately decides that "she must arrange for them to take a long walk together. Foolishly, she had set them opposite each other. That could be remedied tomorrow. If it were fine, they should go for a picnic." 10 With plans like this, Mrs. Ramsay is at her best. "Everything seemed possible. Everything

8. P. 65 .

9. P. 152.

10. P. 157. 
seemed right. Just now (but this cannot last, she thought, dissoclating herself from the moment while they were all talking about boots) just now she had reached security; she hovered like a hawk suspended; like a flag floated in an element of joy which filled every nerve of her body fully and sweetly, not noisily, solemnly rather." 11

The constant demands of her children, her husband and the guests make her feel that "she was nothing but a sponge sopped full of human emotions;"12 yet she cannot forget her duties, her place as hostess. At dinner the whole responsibility is upon her. "Nothing seemed to have merged. They all sat separate. And the whole of the effort of merging and flowing and creating rested on her.....And in pity for him (William Bankes) she began all this business, as a sallor not without weariness sees the wind 1111 his sall and yet hardly wants to be off agaln.... 13 How old she looks, how worn she looks, Lily thought, and how remote. Then when she turned to William Bankes, smiling, it was as if the ship had turned and the sun had struck its sa1ls again. "14

11. P. 157 .

12. P. 51 .

13. P. 126.

14. P. 127. 
It is Indeed a rellef to Mrs. Ramsay when the children have gone to bed, when the house is quiet, and she can forget about setting an example for them and putting her guests at ease.

For now she need not think about anybody. She could be herself, by herself. And that was what now she often felt the need of - to think; well, not even to think. To be silent; to be alone. All the being and the doing, expansive, glittering, vocal, evaporated, and one shrunk with a sense of solemity, to being oneself, a wedge-shaped core of darkness, something invisible to others..... There was a freedom, there was peace, there was, most welcome of al1, a summoning together, a resting on a platform of stability. Not as oneself did one find rest ever, in her experience (she accomplished here something dexterous w1th her needles) but $a s$ a wedge of darkness. Losing personality, one lost the fret, the hurry, the stir; and there rose to her lips always some exclamation in triumph over life when things come together in this peace, this rest, this eternity. 1

In spite of her devotion to him, Mrs. Ramsay is quite sensitive to her husband's faults. She resents his "phrase-making", and his carrying truth to such an extreme that he loses his sense of tact and his ability to hide his emotions. She is quite dazed when he bursts forth with "Damn you" in answer to her hope that the 
weather will be fine. ${ }^{16}$ Again at the dinner table he becomes tremendously angry with poor old Mr. Carmichael, who merely wishes some more soup.

He was screwing up his face, he was scowling and frowning, and flushing with anger...... It was unthinkable, 1t was detestable (so he slgnalled to her across the table) that Augustus should be beginning his soup over again. He loathed people eating when he had finished. She saw his anger fly like a pack of hounds into his eyes, his brow, and she knew that in a moment something violent would explode and then - thank goodness! She saw him clutch himself and clap a brake on the wheel, and the whole of his body seemed to emit sparks but not words. He sat there scowling. He had sald nothing, he would have her observe. Let her give him the credit for that!... Why could he never conceal his feelings? Mrs. Ramsay wondered. 17

Still Mrs. Ramsay does not feel in the least superior or patronizing towards him. She marvels at his intellect, his falrness, his sense of truth. "There was nobody whom she reverenced as she reverenced him. "18 "She had complete trust in him."19 During the dinner conversation, she walts for him to volce his opinion,

For if he sald a thing, it would make all the difference. He went to the heart of things. He cared about fisher-

16. P. 30 .

17. P. 145.

18. P. 51 .

19. P. 178. 
men and the 1r wages. He could not sleep for thinking of them. It was altogether different when he spoke; one did not feel then, pray heaven you don't see how little I care, because one did care. Then, reallzing that 1 was because she admired him so much that she was waiting for him to speak, she felt as $1 f$ somebody had been pralsing her husband to her and their marriage, and she glowed all over without realizing that it wag she herself who had praised him.

As he comes to her for sympathy, so in distress she goes to him for "something more, though she did not know, could not think what it was she wanted." 21 Do say something, she thought, wishing only to hear his volce. For the shadow, the thing folding them in was beginning, she felt, to close round her again. Say anything, she begged, looking at him, as if for help. "22 Recognizing and dreading her mood of despair, of pessimism, "You won't finish that stocking tonight," he said, pointing to her stocking. That was what she wanted - the asperity in his volce reproving her. If he says 1t's wrong to be pessimlstic probably it is wrong, she thought." 23

Yet her own phllosophy does not really change.

20. P. 143 .

21. P. 176.

22. P. 184.

23. P. 184. 
Despite her own comfortable life, she sees the world as a place where no happlness lasts, where misery is possible and probable. Nor does she have God to turn to. When without thinking she says "We are In the hands of the Lord, "24 she is 1mmediately angry with herself. "Who had sald it? Not she; she had been trapped into saying something she did not mean... The insincerity slipping in among the truths roused her, annoyed her... How could any Lord have made this world? she asked. With her mind she had always selzed the fact that there is no reason, order, justice; but suffering, death, the poor. There was no treachery too base for the world to commlt; she knew that. No happiness lasted; she knew that." 25 she despaired at the thought of her children growing up, and losing their young galety and joy. Loving James, she thinks

He will never be so happy again, but stopped herself, remembering how it angered her husband that she should say that. Why take such a gloomy view of iffe? he said. It is not sensible. For it was oda, and she believed it to be true; that with all his gloom and desperation he was happler, more hopeful on the whole, than she was. Less exposed to human worries, perhaps that was 1t. 2.6

And again, "She must admit that she felt this thing that

24. P. 97.

25. P. 98.

26. P. 91. 
she called life terrible, hostile, and quick to pounce on you if you gave it a chance. There were the eternal problems: suffering, death, the poor." 27

It is true that her children are happy now. The reader is given glimpses of them during their busy day, busy as every day is to a child in a large family. James is the baby who is most petted by his mother, perhaps because he 1 s the baby.

Oh, but she never wanted James to grow a day older! or Cam elther. These two she would have liked to keep forever just as they were, demons of wickedness, ongels of delight, never to see them grow up into long legged monsters. Nothing made up for the loss. When she read just now to James, 'And there were numbers of soldiers with kettle drums and trumpets', and his eyes darkened, she thought, why should they grow up and lose all that? He was the most gifted, the most sensitive of her chllaren. But all, she thought, were full of promise. Prue, a perfect angel with the others, and sometimes now, at night especially, she took one's breath away w1 th her beauty. Andrew - even her husband admitted that his gift for mathematics was extraordinary. And Nancy and Roger, they were both wild creatures, now scampering about over the country all day long. As for Rose, her mouth was too big, but she had a wonderful gift w1th her hands. If they had charades, Rose made the dresses; made everything; liked best arranging tables, flowers, anything. She did not like it that Jasper should shoot birds; but 1 t was only a stage; 
they all went through stages. Why, she asked, pressing her chin on James's head, should they grow up so last? Why should they go to schools She would have liked always to have had a baby. She wgr happlest carrying one in her arms. 28

In contrast to Mr. Ramsay, she is perfectly at ease with her chlldren; she seems to realize the Importance of treating them as people with good sense. Especially small James is happlest with his mother: "He hated the twang and twitter of his father's emotion which, vibrating around them, disturbed the perfect simplicity and good sense of his relations with his mother."29 The other children take their father more for granted, admiring his intelligence, his warmth or affection, even daring to laugh at him occasionally so that when Mrs. Ramsay sees her chllaren "with some joke of their own going on, she guessed, from the twitching of their Ilps, something they were hoarding up to laugh over in their own room, "30 she only hopes that it is not about the1r father. Then, with a faint premonition of death, "No, she thought not. What was $1 t$, she wondered sadly rather, for $1 t$ seemed to her that they would laugh when she was not there. "31

28. P. 115.

29. P. 58 .

30. P. 164.

31. P. 164. 
W1th sympathy and understanding she jokes with them, saying emphatically they would not walt dinner for the Queen of England, or the Empress of Mexico, "laughing at Jasper; for he shared his mother's vice; he, too, exaggerated." 32 This same sympathy is reflected as Jasper and Rose are choosing the jewels she shall wear.

But she let them take their time to choose: she let Rose, particularly, take up this and then that, and hold her jewels agalnst the black dress, for this ilttle ceremony of choosing jewels, whlch was gone through every night, was what Rose liked best, she knew. She had some hidden reason of her own for attaching great importance to this choosing what her mother was
to wear. 33

Mrs. Ramsay experiences a let down feeling when

Paul and Minta appear, although they have become engaged.

And for a moment she felt what she had never expected to feel agaln. Jealousy. For he, her husband, felt it too, Minta's glow......But indeed she was not jealous, only, now and then, when she made herself look in her glass a little resentful that she had grown old, perhaps by her own fault. 34

The house becomes quiet as the chllaren and the guests scatter after dinner, and Mr. and Mrs. Ramsay are alone, each reading. For her, "All the odds and

32. P. 120.

33. P. 122.

34. P. 149 . 
ends of the day stuck to this magnet; her mind felt swept, felt clean." 35 She realizes that her husband wants to be reassured of her love, and characteristically she tries to think of something she can do for him to prove her love!

And as she looked at him she began to smile, for though she had not said a word, he knew, of course he knew, that she loved him. He could not deny it. And smiling she looked out of the window and sald (thinking to herself, Nothing on earth can equal this happiness) -

'Yes, you were right. It's golng to be wet tomorrow. You won't be able to go.' And she looked at him smiling. For she had triumphed again, 36 She had not sald 1t: yet he

The full power of Virginia Woolf's prose is demonstrated in the middle portion of the book, which is in striking contrast to the detalled first chapter. Here the most important events in the family life are briefly recorded in parentheses, even the news of Mrs. Ramsay's death, so simply and impersonally told as is word of the death of both Prue and Andrew that it is like a dash of cold water after such a welter of descriptive phrases about the stormy nights, and the restless sleeper seeking an answer to his doubts:

35. P. 181 .

36. P. 186. 
Almost it would appear that it is useless in such confusion to ask the night those questions as to what, and why, and wherefore, which tempt the sleeper from his bed to seek an answer. (Mr. Ramsay, stumbling along a passage one dark morning, stretched h1s arms out, but Mrs. Ramsay having died rather suddenly the night before, h1s arms, though stretched out, remained empty.) 37

First one rainy night passes, then a succession of nights, "full of wind and destruction," 38 bringing with them tarnish and decay, unt1l with a change of seasons,

loveliness relgned and stillness, and together made the shape of loveliness itself, a form from which life had parted..... Loveliness and stillness clasped hands in the bedroom, and among the shrouded jugs and sheeted chairs even the praying of the wind, and the soft nolse of the clamny sea airs, rubbing, snuffling, 1 terating, and relterating the questions - "Will you fade? W11l you perish?" scarcely disturbed the peace, the indifference, the alr of pure integrity, as if the question they asked scarcely needed that they should answer: "We remain." 39

Summer and winter succeed each other unt1l the

house is truly on the brink of decay.

For now had come that moment, that hesitation when dawn trembles and

37. P. 193-194.

38. P. 193.

39. P. 195. 
night pauses, when if a feather al1ght

in the scale $1 t$ will be welghed down.

One feather, and the house, sinking,

falling, would have turned and pitched

downwards to the depths of darkness. 40

However, the feather was w1thheld, and Mrs. McNab and Mrs. Bast, armed with palls and mops, attacked the dirt and corruption, for the Ramsays are returning.

In the final section Lily Briscoe is the most important character. With Lily the reader watches $\mathrm{Mr}$. Ramsay and the children leave on the long postponed lighthouse trip; remembers Mrs. Ramsay and recalls the events of that summer ten years before; and perforce ponders on the mysteries of life 1 tself and the impact of the various characters up on life and one another. Lily despalringly realizes that Mr. Ramsay expects from her the same consolation he obtained from his wife:

This was one of those moments when an enormous need urged him, wi thout being consclous what it was, to approach any woman, to force them, he did not care how, his need was so great, to give him what he wanted: sympathy. 41

Fidgeting, trying to think of some answer, peeved at Mrs. Ramsay for always having humored him so, all she can do is notice his boots.

She was ashamed of herself. To praise his boots when he had shown her

40. P. 208 .

41. P. 225. 
his bleeding hands, his lacerated heart, and asked her to pity them, then to say, cheerfully, "Ah, but what beautiful boots you wear!" deserved, she knew, and she looked up expecting to get it, in one of his sudden roars of 111 temper, complete annihilation. 42

He responds very favorably, however, and happliy shows her a wonderful method of tying a shoelace knot, so that "thus occupled he seemed to her a figure of infinite pathos," 43 and she 1 s angry with Cam and James for their sullenness and lack of enthusiasm as they leave with him.

As she paints, she remembers

Mrs. Ramsay saylng, "Life stands still here", Mrs. Ramsay making of the moment something permanent (as in another sphere Lily herself tried to make of the moment something permanent) re.Mrs. Rameay! Mrs, Ramsay! she 44

Llly's feellngs towards Mrs. Ramsay are full of contradictions. She loved her, almost adored her, yet resented her planning and managing. The thought of Paul's and Minta's unsuccessful marriage brings Lily a feeling of triumph over Mrs. Ramsay as does the fact that she and W1lliam Bankes never married. "What was this mania of hers for marriage? Lily wondered. "45

42. P. 229 .

43. P. 230.

44. P. 241.

45. P. 262. 
And then she remembers Paul the night he became engaged.
Suddenly, as suddenly as a star slides in the sky, a reddish light seemed to burn in her mind, covering Paul Raylay, issuing from him... For a sight, for a glory it surpassed everything in her experience, and burnt year after year like a signal fire on a desert island at the edge of the sea, and one had only to say, "In love" and instantly, as 46 happened now, up rose Paul's fire again. ${ }^{40}$

Lily wonders at the love shared by $\mathrm{Mr}$. and Mrs. Ramsay, the happiness of their relationships, al though she cannot completely understand 1t. She thinks of "the delight in the reward they had, which though the reason of it escaped her, evidently conferred on them the most supreme bliss of which human nature was capable. "47 Then, recalling the not infrequent scenes which upset the household, "It would be a mistake, she thought, thinking how they walked off together, arm in arm, past the greenhouse, to simplify their relationship. It was no monotony of bliss - she with her Impulses and quicknesses; he with his shudders and glooms." 48

She remembers how busy Mrs. Ramsay was, never wasting time, perhaps visiting the poor in a stuffy room, taking them a basket of food.

46. P. 262 .

47. P. 225.

48. P. 296. 
One would be thinking of Greek temples and how beauty had been with them there in that stuffy 11ttle room. She never talked of $1 t$ - she went, punctually, directly. It was her instinct to go, an instinct like the swallows for the south, the artichokes for the sun, turning her infallibly to the human race, making her nest in 1 ts heart. 49

Delving into the past, uncovering the varlous sides of Mrs. Ramsay's character,

One wanted fifty pairs of eyes to see with, she reflected. Fifty pairs of eyes were not enough to get round that one woman with, she thought. Among them must be one that was stone blind to her beauty. One wanted most some secret sense, Iine as air, with which to steal through keyholes to surround her where she sat knitting, talking, sitting silent in the window alone; which took to itself and treasured up like the alr which held the smoke of a steamer, her thoughts, her Imaginations, her desires. 50

During most of the last chapter Lily is working at her overdue plcture of the scene around her. She has long felt frustrated by her inability to portray what her mind can at times vision so clearly. Glancing at the canvas,

She could have wept. It was bad, it was infinitely bad! She could have done it differently of course; the colour could have been thinned and faded; the shapes ethereal1sed; that

49. P. 298.

50. P. 294. 
was how Paunceforte would have seen 1t. But then she did not see it like that. She saw the colour burning on a framework of steel; the light of a butterfly's wing lying upon the arches of a cathedral. Of all that only a few random marks scrawled upon the canvas remained. 51

Attempting that day long ago to explain her meanIng to Mr. Bankes, she Iinds it necessary to take up her brush as ohe talks.

She took up once more her old painting position with the dim eyes and the absent minded manner, subduing all her impressions as a woman to something much more general; becoming once more under the power of that vision which she had seen clearly once and must now grope for among hedges and houses and mothers and chilaren - her picture. 52

Then, ten years later, she seems to feel that if she can Just complete her picture, it will symbolize a drawing together of certain parts of her 11 fe.

Perished. Alone. The grey-green light on the wall opposite. The empty places. such were some of the parts, but how bring them together? she asked..... Suddenly she remembered. When she had sat there last ten years ago there had been a little sprig or leaf pattern on the table-cloth, which she had looked at in a moment of revelation. There had been a problem about a foreground of a pleture. Move the tree to the midale, she had sald. She had never finished that pleture. She would paint that picture now. It had been knocking about

51. P. 75 .

52. P. 82 . 
in her mind all these years..... The question was of some relation between those masses. She had borne it in her mind all these years. It seemed as if the solution had come to her: she knew now what she wanted to do. 53

Yet she still cannot translate her Impression to the canvas.

She had been wasting her morning. For whatever reason she could not achieve that razor edge of balance between two opposite forces; Mr. Ramsay and the picture; which was necessary. There was something perhaps wrong with the design? Was 1t, she wondered, that the line of the wall wanted breaking, was 1t that the mass of the trees was too heavy? She smiled ironically; for had she not thought, when she began that she had solved her problem?..... It was a miserable machine, an inefficient machine, she thought, the human apparatus for painting or feeling; it always broke down at the critical moment; heroloally, one must force 1t on..... Let it come, she thought, if it will come. For there are moments when one can nelther think nor feel. And if one can nelther think nor feel, she thought, where is one? 54

As she walts there, someone in the house sits by

the window, casting a shadow whlch alters the composition of the scene.

It was interesting. It might be useful. Her mood was coming back to her. One must keep on looking without for a second relaxing the intensity of emotion, the

53. P. 220-221.

54. P. $287-288$. 
determination not to be put off, not to be bamboozled. One must hold the scene - so - in a vise and let nothing come in and spoil it. One wanted, she thought, dipping her brush deliberately, to be on a level with ordinary experlence, to feel simply that's a chalr, that's a table, and yet at the same time, 1t's a miracle, 1t's an ecstasy. 55

As she looked out over the sea, In the distance she discovers that the boat has reached the lighthouse. With a sigh of relief and exhaustion, she turns to old Mr. Carmichael standing beside her, "looking like an old pagan god, shaggy, with weeds in his hair and the trident (it was only a French novel) in his hand, "56 a. he says, "They will have landed." She feels the communion of spirit with him that she had felt a few moments before as he dozed near her:

She felt that she had been right. They had not needed to speak. They had been thinking the same things and he had answered her wi thout her asking him anything. He stood there as if he were spreading his hands over all the weakness and suffering of mankind; she thought he was surveying, tolerantly and compassionately, their inal destiny. 5 ?

In a mood of satisfied fulfillment, she quickly turns to her canvas.

$$
\begin{array}{lll}
\text { 55. } & \text { P. } & 300 . \\
56 . & \text { P. } & 309 \\
\text { 57. } & \text { P. } & 309 .
\end{array}
$$


There 1 was - her pleture. Yes, with all its greens and blues, its lines running up and across, its attempt at something. It would be hung in the attics, she thought; it would be destroyed. But what did that matter? she asked herself, taking up her brush again. She looked at the steps; they were empty; she looked at her canvas; it was blurred. With a sudden intensity, as if she saw it clear for a second, she drew a Iine there, in the center. It was done; it was finished. Yes, she thought, laying down her brush in extreme fatigue, I have had my vision. 58

Interwoven with Lily's reverie is the trip to the 11ghthouse with 1 ts rather tense atmosphere, and silent, but none the less real, struggle between Mr. Ramsay on one hand and Cam and James on the other. Both children are flercely resentful of the fact that they were forced to come.

Speak to him they could not. They must come; they must follow. They must walk behind him carrying brown paper parcels. But they rowed, in silence, as they walked, to stand by each other and carry out the great compact - to resist tyranny to the death. So there they would sit, one at one end of the boat, one at the other, in silence. 59

Cam begins to weaken as she watches her father Ilsten to Macalister's story about a boat sinking, men arowning.

58. P. 309-310.

59. P. 243. 
Cam thought, feeling proud of him without knowing quite why, had he been there he would have launched the lifeboat, he would have reached the wreck, Cam thought. He was so brave, he was so adventurous, Cam thought. But she remembered. There was the compact; to resist tyranny to the death. Their grievance welghed them down. They had been forced; they had been bidden.

Her father realizes that something is wrong, and gently tries to smooth over their relationship.

I will make her smile at me, he thought. She looks irlghtened. She was so sllent. He clutched his fingers, and determined that his volce and his face and all the quick expressive gestures which had been at his command making people pity him and praise him all these years should subdue themselves. He would make her smile at him. He would find some simple easy thing to say to her. But what? For, wrapped up in his work as he was, he forgot the sort of thing one sald. There was a puppy. They had a puppy. Who was looking after the puppy today? he asked. Yes, thought James pitilessly, seeing his sister's head against the sa11, now she w1ll give way. 61

In splte of his fear, Cam does not yleld, although she yearns to answer her father. She can find no way to remain

Plerce and loyal to the compact, yet passing on to her father, unsuspected by James, a private token of the love she felt for him... For she thought, looking at James who kept his eyes dispassionately on the sall, or glanced now and then for a second at the horizon,

60. P. 246 .

61. P. 250. 
you're not exposed to it, to this pressure and division of feeling, this

W1th maturity of thought, she realizes the great attraction her father has for her in spite of his temper and his tyranny.

James' resentment stems from his father's harshness on that day ten years before when he so firmly stated that the trip was impossible. Since then "He had always kept this old symbol of taking a knlfe and striking his father to the heart. "63 Yet he too is subjected to the division of emotion which overcomes Cam, for "As he grew older, and sat staring at his father in an impotent rage, it was not him, that old man reading, whom he wanted to kill, but it was the thing that descended on him - without his knowing it perhaps..... 64 He had come to feel, quite often lately, when his father sald something or did something which surprised the others, there were two pairs of footprints only; his own and his father's. They alone knew each other." 65

Dragging her hand through the waves, Cam feels a "fountain of joy at the change, at the escape, at the 62. P. 252. 63. P. 273. 64. P. 273. 65. P. 275. 
adventure (that she should be alive, that she should be there)." 66 Her thoughts of her father become more tender, and she thinks "He was not vain, nor a tyrant and did not wish to make you pity him. Indeed, if he saw she was there, reading a book, he would ask her, as gently as anyone could, was there nothing he could give her? 167

As they near the Lighthouse, Mr. Ramsay says triumphantly "Well done!' James had steered them like a born sallor. There! Cam thought, addressing herself silently to James. You've got it at last. For she knew that this was what James had been wanting and she knew that now he had got it he was so pleased that he would not look at her or at his father or at anyone. "68 The end of the trip, therefore, brings a surge of affection for their father that engulfs their past bitterness, so that they both wish to express their feeling in some way:

They watched him, both of them, sitting bare-headed with his parcel on his knee staring and staring at the erail blue shape which seemed like the vapour of something that had burnt itself away. What do you want? they both wanted to ask. They both wanted to say, ask us anything and we will give it you. But he did not ask them anything. He sat

66. P. 280 .

67. P. 282.

68. P. 306. 
and looked at the island and he might be thinking, We perished, each alone, or he might be thinking, I have reached it. 69 have found 1t; but he sald nothIng. 69

In this book Virginia Woolf's power of meditation is indeed blended w1th her sense of narrative so that an effective and delicate balance is achieved. At the end Lily with renewed vision completes her picture, and as they finally reach the lighthouse, Cam and James experience a feeling of sympathy and gratitude for their father. Not only are all the threads of the story tastefully interwoven but also psychological finesse and insight blend with artistic unity in producing a capital story.

69. P. 308. 
Virginia Woolf might easily be classified as a romantic naturalist, since her whole, pratical philosophy seems to be based, not upon any belief in the existence of God and eternal life of the individual soul, but rather on a reliance upon Nature and the entire Universe. And though she keeps, or contrives to keep, the past and present in an almost intimate relation, yet there is scarcely a reference to or recognition of the future as such, except the constant awareness and haunting fear of the passing of time, ending in inevitable and imminent death. The incessant repetition of the processes of Nature, and their indifference to the needs and desires of man not only fascinated Virginia Woolf, but also formed a basic part of her productive thought I1fe.

Along with this high regard for Nature is a deep interest in daily living. Virginia Woolf, a person of tremendous zest, enjoyed life keenly in spite of its terrors. She felt that 1 ts hidden meanings and worths were often revealed by little flashes of insight, so that certain moments and signal experiences are indelibly 
recorded on the human consclousness. These cruclal 1lluminations she deemed especially necessary for understanding other people; and while she was tremendously interested in all human relationships and adjustments, yet she fully realized the difficulty of thoroughly knowlng another person. Her chlef concern, however, with other persons was restricted to individuals rather than to classes, for Virginia Woolf's soclal consclousness was never too highly developed. A naturalist, then, vitally aware of the forces of the universe, deeply concerned with the problems of life and death, always striving to evaluate the complex reactions of the human consclousness - this is Virginia Woolf. These maln aspects of her philosophy are reflected not only in the general themes of her novels, but more directly through the author-controlled lyrical passages, and indirectly as she reveals her thought processes in the reflections of her characters, which appear in the utterances both of Mrs. Ramsay, with whom Virginia Woolf obviously sympathizes, and of Septimus Sm1th, whose neurotic outlook 18 given importance by repetition. By elaborating these suggestions this chapter will attempt to illustrate more fully Virginla Woolf's philosophy. 
Nowhere in the publications of Virginia Woolf does there appear a positive bellef in God. She seems to feel that the world 1 s too cold and cruel to be dominated by any personal being and that the universe is a purely mechanical affalr which merely repeats its neverending and monotonous cycles. So when Mrs. Ramsay inadvertently thinks of the Lord, she becomes angry with herself:

What brought her to say that: "We are in the hands of the Lord?" she wondered. The insincerity slipping in among the truths roused her, annoyed her. She returned to her knltting again. How could any Lord have made this world? she asked. With her mind she had always seized the fact that there is no reason, order, justice: but suffering, death, the poor. There was no treachery too base for the world to commlt: she knew that. No happiness lasted; she knew that. 1

Mrs. Dalloway joins with Mrs. Ramgay in affirming "Not for a moment did she believe in God." 2 Mrs. Dalloway's substltute seems to be a sort of transcendental belief that after death individuals live on elther in places they have inhabited or in people they have known:

Did it matter then, she asked herself, walking towards Bond Street, did it matter that she must inevitably cease completely; all this must go on without her; did she resent 1t; or did it not become consoling to believe that death

1. Woolf, Virginia, To The Lighthouse, p. 98.

2. Woolf, Virginia, Mrs. Dalloway, p. 43. 
ended absolutely? but that somehow in the streets of London, on the ebb and flow of things, here, there, she survived, Peter survived, lived in each other, she being part, she was positive, of the trees at home; of the house there, ugly, rambling, all to bits and pleces as it was; part of people she had never met; being lald out like a mist between the people she knew best, who lifted her on their branches as she had seen the trees lift the mist, but $1 t_{3}$ spread ever so far, her life, herself. 3

Peter re-states her bellef with a slightly different emphas18:

She belleved (for all her scepticism), that since our apparitions, the part of us whlch appears, are so momentary compared with the other, the unseen part of us, which spreads wide, the unseen might survive, be recovered somehow attached to this person or that, or even haunting certain places after death.

This view of the individual, so small when compared with nature and the eternity of the universe, is constantly appearing in Virginia Woolf. A sense of the brevity of life, of the flow and change that are felt by all her major characters. In Jacob's Room Virginia Woolf states it thus: "In any case 11 fe is but a procession of shadows, and God knows why it is that we embrace them so eagerly, and see them depart with such anguish, being shadows." 5

3. Ibld., p. 12 .

4. Ibld., p. 232.

5. Woolf, Virginia, Jacob's Room, p. 118. 
The passage of time is strongly felt by Mrs. Dalloway: "But she feared time 1tself, and read on Lady Bruton's face, 8.8 if it had been a dial cut in impassive stone, the dwindling of life; how year by year her share was sliced... feeling herself suddenly shrivelled, aged, breastless. "6 6 Death often enters Clarissa's mind, for as she thinks about the routine of her life, she concludes, "It was enough - after that, how unbelievable death was! - that 1 t must end."

Nature's ever-changing cycle is also portrayed:

So on a summer's day waves collect, overbalance, and fall; collect and fall; and the whole world seems to be saying 'that is all' more and more ponderously, until even the heart in the body which lies in the sun on the beach says too, That is all. Fear no more, says the heart. Fear no more, says the heart, committing its burden to some sea, which sighs collectively for all sorrows, and renews, begins, collects, lets fali. 8

One of Virginia Woolf's most impressively developed symbols along this line is pictured in the singing, beggar woman, the old "rusty pump" in Mrs. Dalloway. Her volce is "the volce of no age or sex, the volce of an ancient spring spouting from the earth. " 9 As the symbol of eternal womanhood and of eternal love, she

6. Woolf, Virginia, Mrs. Dalloway, p. 44-45.

7. Ib1d., p. 185 .

8. Ibid., p. 58-59.

9. Ib1d., p. 122 . 
sings now and forever of her lover of a million years ago:

Through all ages - when the pavement was grass, when it was swamp, through the age of tusk and mammoth, through the age of sllent sunrise, the battered woman - for she wore a skirt - with her right hand exposed, her left clutching at her side, stood singing of love, - love which has lasted a mililon years, she sang, love which prevalls, and mililions of years ago, her lover, who had been dead these centuries, had walked, she crooned, with her in May; but in the course of ages, long as summer days, and flaming, she remembered, with nothing but red asters, he had gone; death's enormous sickle had swept those tremendous hills, and when at last she lald her hoary and Immensely aged head on the earth, now become a mere cinder of 1ce, she 1mplored the Gods to lay by her side a bunch of purple heather, there on her high burlal place whlch the last rays of the last oun caressed; for then the pageant of the universe would be over... still remembering how once in some primeval May she had walked with her lover, this rusty pump, this battered old woman with one hand exposed for coppers the other clutching her side would st1ll be there in ten million years, remembering how once she had walked in May, where the sea flows now, with whom 1t did not matter - he was a man, oh, yes, a man who had loved her... She smiled, pocketing her shilling, and all peering inquisitive eyes seemed blotted out, and the passing generations - the pavement was crowded with bustling middle-class people - vanished, like leaves, to be trodden under, to be soaked and steeped and made mould of by that eternal spring ee um fah um so foo swee too eem oo 10

10. Ib1d., p. 123-124. 
Mrs. Ramsay and Lily, in To The Lighthouse, are both 1mpressed by a sense of fleeting time. The waves beating on the beach, the constant circle of the light from the Lighthouse, the 1llusion of being completely isolated from the rest of the world by the sea - all these enhance such a feeling. To Mrs. Ramsay, the sound of the waves "like a ghostly roll of drums remorgelessly beat the measure of $11 f e$, made one think of the destruction of the 1sland and its engulfment in the sea, and warned her whose day had slipped past in one quick doing after another that 1 t was all ephemeral as a rainbow." 11

Again, "Only she thought life - and a little strip of time presented itself to hereyes - her fifty years. There 1t was before her - 11fe. "12

Even Mr. Ramsay is affected by the sense of the smallness of one's existence:

They would stem the flood a bit. That was a good bit of work on the whole h1s elght chlldren. They showed he did not damn the poor little unlverse entirely, for on an evening like this, he thought, looking at the land dwinding away, the iftle island seemed patheticaliy smali, half swallowed up in the sea. "Poor little place," he murmured with a sigh. 13

11. Woolf, Virginia, To The Lighthouse, p. 28. 12. Ibid., p. 91.

13. Ib1d., P. 106. 
Nancy, playing by a small pond full of minnows and plants, becomes aware of the hugeness of the nearby sea in comparison:

She became with all the power sweeping savagely in and inevitably wi thdrawing, hypnotised, and the two senses of that vastness and this tininess (the pool had diminished again) flowering within it made her feel that she was bound hand and foot and unable to move by the intensity of feelings which reduced her own body, her own life, and the lives of all the people in the world, forever, to nothingness. 14

Lily Briscoe, watching the sea and the dunes, feels a certain sadness, "partly because distant views seem to outlast by a million years (L1ly thought) the gazer and to be communing already with a sky which beholds an earth entirely at rest." 15

In the lyrical and emotional "T1me Passes", when nature so nearly takes over the summer home, destroying all traces of habltation, the tremendous power of nature and her insensibility to mankind is stressed: "Did nature supplement what man advanced? Did she complete what he began? With equal complacence she saw his misery, his meanness, and his torture.... 16 what power could now prevent the fertility, the insensibility of nature? 17

14. Ib1d., p. 115.

15. Ibla., p. 34.

16. Ib1d., p. 202 .

17. Ib1d., p. 207. 
Perhaps Virginia Woolf regarded her writing as the one thing from out of the smallness of her life that would endure, because in her main characters, each seems to have one special contribution that is her challenge to death and obscurity. Mrs. Dalloway has her parties: "Nothing else had she of the slightest importance: could not think, write, even play the plano." 18 Mrs. Ramsay has her ever-flowing well of sympathy, her power to draw together, merge, and soothe.

As for Lily, painting is her answer to the inescapabillty of death, to the eternity of nature and the universe. Silently conversing with Mr. Carmichael, she thinks, "that would have been his answer, presumably, how 'you' and 'I' and 'she' pass and vanish; nothing stays; all changes; but not words, not palnt. "19

Away from the gigantic concepts of the universe, Virginia Woolf seems to feel that there is a certain exuberance and excitement contained in everyday life. Jacob feels a youthful joy in such simple situations as talking with a friend, walking down the road, or boating with Timmy:

Now Jacob began plunging about, half to stretch himself, half in a kind of jollity,

18. Woolf, Virginia, Mrg. Dalloway, p. 185.

19. Woolf, Virginla, To The L1ghthouse, p. 267. 
no doubt, for the strangest sound issued from his lips as he furled the sall, rubbed the plates - gruff, tuneless - a sort of paean, for having grasped the argument, for being master of the situation, sunburnt, unshaven, capable into the bargain of salling round the world in a ten-ton yacht, which, very $11 \mathrm{kely}$, he would do one of these days instead of settling down in a lawyer's office and wearing spats. 20

Mrs. Dalloway especially is full of this vivacious-

ness:

For Heaven only knows why one loves it so, how one sees it so, making it up, building it round one, tumbling it, creating it every moment afresh; but the veriest frumps... do the same; can't be dealt with, she felt positive, by Acts of Parliament for that very reason; they love life... In the triumph and the Jingle and the strange high singing of some aeroplane overhead was what she loved; 11fe; London; this moment of June. 21

Peter says of her, "And of course she enjoyed 11 fe 1mmensely. It was her nature to enjoy... She enjoyed practically everything. "22

Counteracting this sense of animation, however, is the somber and oft-repeated thought that the world is impersonal, bitter, cruel and treacherous; that no happlness lasts; that loneliness and death are always waiting. As Virginia Woolf states in Jacob's Room,

20. Woolf, Virginia, Jacob's Room, p. 80. 21. Woolf, Virginia, Mrs. Dalloway, p. 5. 22. Ib1d., p. 118. 
"Indeed, there has never been any explanation of the $e b b$ and flow in our veins - of happlness and unhapp1ness." 23 While Jacob watches the Cornish hills, the author meditates about him:

Somehow or other, loveliness is infernaliy sad. Yes, the chimneys and the coastguard stations and the little bay with the waves breaking unseen by any one make one remember the overpowering sorrow. And what can this sorrow be?

It is brewed by the earth 1 tself. It comes from the houses on the coast. We start transparent, and then the cloud thlckens. All history backs our pane of glass. To escape is vain. 24

Septimus Sm1th and Mrs. Dalloway are psychologically bound together by a fear of 11 fe and a terror of the world. Hearing the news of Septimus' death, Clarissa thinks, "Then (she had felt it only this morning) there was the terror; the overwhelming incapacity, one's parents giving it into one's hands, this life, to be Iived to the end, to be walked with serenely; there was in the depths of her heart an awful fear. "25 And Septimus, unable to face this terror, was constantly haunted by a fear of loneliness along with a sort of a horror of mankind:

For the truth is (let her ignore it) that human beings have neither kindness, nor falth, nor charlty beyond

23. Woolf, Virginia, Jacob's Room, p. 235. 24. Ibid., p. 78.

25. Woolf, Virginia, Mrs. Dalloway, p. 281. 
what serves to increase the pleasure of the moment. They hunt in packs. Their packs scour the desert and vanish screaming into the wilderness. They desert the fallen. 26

Mrs. Ramsay too is aware of the imperfections of human beings, "aware of the pettiness of some part of her, and of human relations, how flawed they are, how desplcable, how self-seeking at their best." 27 she feels that she is constantly engaged in a struggle with 11fe, trying to make the best of an impossible situation:

A sort of transaction went on between them (herself and Life) in which she was on one side, and life was on another, and she was always trying to get the better of $1 t$, as it was of her; and sometimes they parleyed (when she sat alone); there were, she remembered, great reconciliation scenes; but for the most part, oddly enough, she must admit that she felt this thing that she called life terrible, hostile, and quick to pounce on you if you gave it a chance. There were the eternal problems: suffering, death; the poor. There was always a woman dylng of cancer over here. And yet she had said to all these children, You shall go through 1t al1...... For that reason, knowing what was before them - love and ambltion and being wretched alone in dreary places - she had often the feeling, Why must they grow up and lose it all? And then she sald to herself, brandishing her sword at life Nonsense. They w1ll be perfectly happy. 28

26. Ib1d., p. 135.

27. Woolf, V1rginia, To The L1ghthouse, p. 66. 28. Ibid., p. 92 . 
Discouraged as she may be concerning the level of human's behavior, V1rginla Woolf constantly meditates on the human character in relation to 1 tself and to others. Reflected in her storles and in her characters is the basic thought that one individual can never really know and understand another, so that "it seems that a profound, impartial, and absolutely just opinion of our fellow creatures is utterly unknown. "29 Never does Virginia Woolf evaluate her characters, explain their motives or their actions for the reader. Generally the reader is left to ferret out the best he can not only what the characters themselves think but also their reactions and the other responses to the other characters. Thus we have it in Jacob's Room: "It is no use trying to sum people up. One must follow hints, not exactly what is said, nor yet entirely what is done." 30

Th1s whole novel is based upon the principle of presenting a character through such hints, but relying malnly upon those given by Jacob's associates. Virginia Woolf recognizes that even this is an incomplete method of character study:

The proximity of the omnibuses gave the outside passengers an opportunity to stare 1nto each other's faces. Yet few

29. Woolf, Virginia, Jacob's Room, p. 118. 30. Ib1d., p. 262 . 
took advantage of 1t. Each had his own business to think of. Each had h1s past shut in him like the leaves of a book known to hlm by heart; and his friends could only read the title, James Spalding, or Charles Budgeon, and the passengers going the opposite way could read nothing at all - save "a man with a red moustache," "a young man in grey smoking a pipe." 31

And such physical descriptions mean very little, for the essence of personality is what is important: "But surely of all futile occupations this of cataloguing features is the worst. One word is sufficlent. But if one cannot find 1t?"32

Certainly in Mrs. Dalloway the most important characters examine themselves and each other. Peter is more emotional and hasty in his decisions; Richard is calm and tolerant, while Clarissa varies; yet she is consistent in one thing: "She would not say of any one in the world now that they were this or were that. She felt very young; at the same time unspeakably aged..... and she would not say of Peter, she would not say of herself, I am this, I am that. $" 33$

Perhaps this conviction stems from her realization that she herself has so many sides:

31. Ib1d., p. 105.

32. Ib1d., p. 116.

33. Woolf, Virginia, Mrs. Dalloway, p. 11. 
That was hergelf - pointed; dartilke; definite. That was herself when some effort, some call on her to be herself drew the parts together, she alone knew how alfferent, how incompatible and composed so for the world only into one center, one diamond, one woman who sat in her drawing-room and made a meeting-point, a radiancy no doubt in some dull lives, $\varepsilon$ refuge for the lonely to come to, perhaps; she had helped young people, who were grateful to her; had tried to be the same always, never showIng a sign of all the other sides of her faults, jealousies, vanities, susplcions, like this of Lady Bruton not asking her to lunch; which, she thought (combing her hair finaliy), is utterly base! Now where was her dress?34

Along with Clarissa's theory of how difficult it is to know someone else is 1 ts corollary that the best method of making such an effort is to be familiar with that someone's background, family and friends. According to Peter:

They [Clarissa and Peter] had heaps of theortes, always theorles, as young people have. It was to explain the feeling they had of dissatisfaction; not knowing people; not being known. For how could they know each other? You met every day; then not for six months, or years.

It was unsatisfactory, they agreed, how little one knew people. But she said, sitting on the bus going up shaftesbury Avenue, she felt herself everywhere; not "here, here, here"; and she tapped the back of the seat; but everywhere. She waved her hand, golng up shaftesbury

34. Ib1d., p. 55. 
Avenue. She was all that. So that to know her, or any one, one must seek out the people who completed them; even the places. Odd affinities she had with people she had never spoken to, some woman in the street, some man behind a counter - even trees, or barns. 35

In To The Lighthouse, Lily Briscoe is generally seen as the ponderer, the meditator. Confused by her contradictory feelings regarding both Mr. Bankes and Mr. Ramsay, she wonders:

How then did it work out, all this?

How did one judge people, think of them?

How did one add up this and that and

conclude that it was liking one felt, or meaning attached, after al1936

Filled with love and admiration, she sits close to

Mrs. Ramsay, wildy hoping that by some means she can

become a definite part of her secret, inner compartments of beauty and wisdom:

What art was there, known to love or cunning, by which one pressed through into those secret chambers? What device for becoming, like waters poured into one jar, inextricably the same, one with the object one adorea? Could the body achleve, or the mind, subtly mingling in the intricate pasaages of the brain? or the heart? Could loving, as people called it, make her and Mrs. Ramsay one? for 1t was not knowledge but unity that she desired, not inscriptions on tablets, nothing that could be written in any language known to men, but intimacy itself,

35. Ibid., p. 231.

36. Woolf, Virginia, To The Lighthouse, p. 40. 
wh1ch is knowledge, she had thought, leaning her head on Mrs. Ramsay's knee. Nothing happened. Nothing!

Nothing! as she leant her head against Mrs. Ramsay's knee. And yet, she knew knowledge and wisdom were stored up in Mrs. Ramsay's heart. How then she had asked herself, did one know one thing or another thing about people, sealed as they were? 3 ?

Lily realizes, then, that our attempts to know each other are generally unsuccessful, and the results even occasionally ridiculous: "Who knows what we are, what we feel? Who knows even at the moment of intimacy, This is knowledge?"38 "Half one's notions of other people were, after all, grotesque. They served private purposes of one's own." 39

Virginia Woolf seems to feel that whether or not an Individual fully knows another person, yet he yearns for companionship; there is always a feeling of loneliness about her characters. Jacob is sad as he watches the Greeks passing by his window: "Their lack of concern for him was not the cause of his gloom; but some more profound conviction - it was not that he himself happened to be lonely, but that all people are"; 40 Clarissa, shaken by Richard's lunching with Lady Bruton, thinks, "He has

37. Ib1d., p. 79.

38. Ib1d., p. 256.

39. Ib1d., p. 293.

40. Woolf, Virginia, Jacob's Room, p. 238. 
left me; I am alone forever" $;^{41}$ And to Mr. Ramsay the phrase keeps recurring; "We perished each alone. "42 Peter, going to the party, realizes this need for friends:

For this 18 the truth about our soul, he thought, our self, who flshlike inhabits deep seas and plies among obscurlties threading her way between the boles of giant weeds, over sunflickered spaces and on and on into gloom, cold, deep, inscrutable; suddenly she shoots to the surface and sports on the wind-wrinkled waves; that is, has a positive need to brugh, scrape, kindle herself, gossiping. 43

The relation between the sexes interests Virginia Woolf considerably. Love between a man and a woman is at once horrible and beautiful, at once full of bliss and full of terror. With a sudden bitterness and gealousy, Clarissa thinks how detestable love is: "The cruelest things in the world, she thought, seeing them clumsy, hot, domineering, hypocritical, eavesdropping, jealous, infinitely cruel and unscrupulous, dressed in a mackintosh coat, on the landing; love and religion..... Love destroyed too. Everything that was fine, everything that was true went." 44 Yet when she 1s w1 th Peter, "extraordinarlly at her ease with him and light-hearted,

41. Woolf, V1rginla, Mrs. Delloway, p. 70.

42. Woolf, Virginia, To The Lighthouse, p. 247, 249, 253. 43. Woolf, Virginia, Mrs. Dalloway, p. 244 . 44. Ib1d., p. 191-192. 
all in a clap $1 \mathrm{t}$ came over her, If I had marrled him, this galety would have been mine all day. "45

Even Lily Briscoe is fascinated by Paul's and

Minta's love:

It is so beautiful, so exciting, this love, that I trembie on the verge of $1 t$, and offer, quite out of my own hab1t, to look for a brooch on a beach; also it is the stupldest, the most barbaric of human passions, and turns a nice young man with a propile like a gem's (Paul's was exqu1site) into a bully with a crowbar (he was swaggering, he was insolent) in the Mile End Road. Yet, she sald to herself, from the dawn of time odes have been sung to love; wreaths heaped and roses; and if you asked nine people out of ten they would say they wanted nothing but this - love; while the women, judging from her own experience, would all the time be leeling, This is not what we want; there is nothing more tedious, puerile, and inhumane than this; yet it is also beautiful and necessary. 46

Ten years later she is wondering about Mrs. Ramsay's manla for marriage, and

(Suddenly, as suddenly as a star slides in the sky, a reddlsh light seemed to burn in her mind, covering Paul Raylay, issulng from him. It rose like a fire sent up in token of some celebration by savages on a distant beach. She heard the roar and the crackle. The whole sea for miles round ran red and gold. Some winey smell mixed with it and intoxicated her, for she felt again her own headlong

45. Ib1d., p. 70.

46. Woolf, Virginia, To The Lighthouse, p. 154-155. 


\begin{abstract}
desire to throw herself off the cliff and be drowned looking for a pearl brooch on a beach. And the roar and the crackle repelled her with fear and disgust, as if while she saw its splendour and power she saw too how it fed on the treasure of the house, greedily, disgustingly, and she loathed 1t. But for a sight, for a glory it surpassed everything in her experience, and burnt year after year like a signal ilre on a desert 1sland at the edge of the sea, and one had only to say "in love" and instantly, as happened now, up rose Paul's flre again. And it sank and she sald to herself, laughing, "The Rayley's"; how Paul went to coffeehouses and played chess. ${ }^{4}$ ?
\end{abstract}

In marriage there can be achieved a certain stability, a certain security which is so necessary to the individual. In her sadness, Clarissa wants Richard: "Rlchard, Richard! she cried, as a sleeper in the night starts and stretches a hand in the dark for help. "48 And in her fear and terror of life, "Even now, quite often if Richard had not been there reading the Iimes, so that she could crouch like a bird and gradually revive, send roaring up that immeasurable delight, rubbing stick to stick, one thing w1th another, she must have perished. "49 The mutual dependence of the Ramsays has been previously discussed, but along with their need for each other $1 \mathrm{~s}$ an intimacy and an understanding, even the lack

\footnotetext{
47. Ibid., p. 261-262.

48. Woolf, Virginia, Mrs. Dalloway, o. 70. 49. Ib1d., p. 281-282.
} 
of need for speech at times. So Mrs. Ramsay can let her husband know of her love without saying a word:

Then, knowing that he was watching her, instead of saying anything, she turned, holding her stocking, and looked at him. And as she looked at him she began to silile, for though she had not said a word, he knew, of course he knew, that she loved him. He could not deny 1 t. And smiling, she looked out of the window and sald (thinking to herself, Nothing on earth can equal this happiness) - "Yes, you were right. It's going to be wet tomorrow. You won't be able to go." And she looked at him smiling. For she had triumphed again. She had not said 1t; jet he knew. 50

Quite similar to this is the passage in Mrs.

Dalloway where Richard comes in with the flowers, determined to tell Clarlssa of hls love for her.

(But he could not bring himself to say he loved her; not in so many words.) But how lovely, she sald, taking his flowers. She understood; she understood without his speaking; his Clarissa..... (But he could not tell her he loved her. He held her hand. Happiness is this, he thought. $) 51$

Nevertheless in all love relations Virginia Noolf seems to feel that there is danger of too much demand as well as too little privacy of the soul. Clarissa reassures herself that she was right not to marry Peter, because "In marrlage a little license, a little lndependence, there must be between people living together day in

50. Woolf, Virginia, To The Lighthouse, p. 185-186.

51. Woolf, Virginia, Mrs. Dalloway, p. 179-180. 
day out in the same house." 52

Even Mrs. Ramsay, full of sympathy and love, becomes exhausted by the emotional demands of her husband: "So boasting of her capacity to surround and protect, there was scarcely a shell of herself left for her to know herself by." 53 Lily in retrospect criticizes Mrs. Ramsay for glving so much of herself to anyone: "Mrs. Ramsay had given. Giving, giving, giving, she had dled - and had left all this. Really, she was angry wth Mrs. Ramsay." 54

The only real and clear meaning of life as seen by Virginia Woolf seems to be a series of small, stabilized, exquisite moments that are like matches $11 \mathrm{t}$ in the darkness of the world. Clarissa, pondering on the intimacy she has experienced with various women friends, recognizes such an illumination:

Only for a moment; but it was enough:

It was a sudden revelation, a tinge

like a blush which one tried to check and then, as it spread, one ylelded to its expansion, and rushed to the farthest verge and there quivered and felt the world come closer, swollen with some astonishing signiflcance, some pressure of rapture, whlch spilt 1ts thin skin and gushed and poured with an extraordinary alleviation over the cracks and sores! Then, for that moment, she had seen an illumination;

52. Ibid., p. 52.

53. Woolf, Virginia, To The Lighthouge, p. 60. 54. Ibid., p. 223. 
a match burning in a crocus; an inner meaning almost expressed. 55

Lily also feels that the "little dally miracles", the permanent memories, are what count in the world so full of change and chaos:

The great revelation had never come. The great revelation perhaps never did come. Instead there were little dally miracles, illuminations, matches struck unexpectedly in the dark; here was one. Th1s, that, and the other; herself and Charles Tansley and the breaking wave; Mrs. Ramsay bringing them together; Mrs. Ramsay saying, "Life stand still here"; Mrs. Ramsay making of the moment something permanent (as in another sphere lily herself tried to make of the moment something permanent) - this was of the nature of a revelation. In the midst of chaos there was shape; th1s eternal passing and flowing (she looked at the clouds going and the leaves shaking) was struck into stability. Life stand still here, Mrs. Ramsay said. 56

At the dinner table Mrs. Ramsay suddenly experiences a feeling of security, of suspension from the rush of time whlch seemed to bind the group together:

There is a coherence in things, a stability; something, she meant, is immune from change, and shines out (she glanced at the window with 1 ts ripple of reflected lights) in the face of the flowing, the fleeting, the spectral, like a ruby; so that again tonight she had the feeling she

55. Woolf, Virginia, Mrs. Dalloway, p. 47. 56. Woolf, Virginia, To The Lighthouse, p. 241. 
had had once today, already, of peace, of rest. Of such moments, she thought, the thing is made that endures. 57

The memory of Mrs. Ramsay sitting by her side discussing the expressive power of sllence seems suddenIy Important to Lily, and she marks another one of those stabilized moments: "The moment at least seemed extraordinarily fertile. She rammed a little hole in the sand and covered it up, by way of burying in it the perfection of the moment. It was like a drop of silver In whlch one dipped and lllumined the darkness of the past." 158

Virginia Woolf seems to feel that there are some people whose mission it is to combine, to create, to bring together disparate elements. In Jacob's Room she says: "'Try to penetrate,' for as we lift the cup, shake the hand, express the hope, something whispers, Is this al1? Can I never know, share, be certain?" 59 And again in To The Lighthouse, Lily thinks, "There might be lovers whose gift it was to choose out the elements of things and place them together and so, giving them a wholeness not theirs in life, make of some scene, or meeting of people (all now gone and separate), one of

57. Ibid., P. 158.

58. Ib1d., p. 256.

59. Woolf, Virginia, Jacob's Room, p. 156. 
those globed compacted things over which thought lingers, and love plays. "60

Mrs. Ramsay is filled with a sense of her responsibility for bringing together any group of which she is a part. At the dinner table,

Nothing seemed to have merged. They all sat separate. And the whole of the effort of merging and flowing and creating rested on her. Again she felt, as a fact without host1lity, the sterility of men, for if she did not do it nobody would do it, and so, giving herself the little shake that one gives a watch that has stopped, the old famlliar pulse began beating, as the watch begins ticking - one, two, three, one, two, three. 61

Although no one is sympathetic with Mrs. Dalloway's Impulse to give parties, they are very important to her. She thinks of all her friends who are so separate and lonely and feels that she must at least do something to bring everyone together. "And 1t was an offering; to combine, to create; but to whom? An offering for the sake of offering, perhaps. Anyhow, it was her gift. Nothing else had she of the slightest importance." 62 Along with this responsibility for stablizing and bringing together is the conviction that although life and the world are menacing and terrifying, one's duty

60. Woolf, Virginia, To The Lighthouse, p. 286. 61. Ib1d., p. 126.

62. Woolf, Virginia, Mrs. Dalloway, p. 185. 
demands the little kindnesses and a certain graciousness and thoughtfulness. So 1 t comes about that Mrs. Ramsay is struck by plty for Charles Tansley and asks him to go with her to town; for Augustus Carmichael and asks if she can bring him anything; for Mr. Bankes and tries to draw him in the family circle.

Mrs. Dalloway is also similarly impressed that she must repay all those rapturous moments she has experlenced:

Moments like this are buds on the tree of life, flowers of darkness they are, she thought (as if some lovely rose had blossomed for her eyes only); not for a moment did she belleve in God; but all the more, she thought, taking up the pad, must one repay in dally life to servants, yes to dogs and canaries, above all to Rlchard her husband, who was the foundation of 1 t - of the gay sounds, of the green lights, of the cook even whistilng, for Mrs. Walker was Irish and whistled all dey long one must pay back from this secret
deposit of exquisite moments, she thought. 63

Peter states practically the same thing a little

less sentimentally even if a little more crudely:

Possibly she said to herself, as we are a doomed race, chained to a sinking ship, (her favorite reading as a girl was Huxley and Tyndall, and they were fond of these nautical metaphors), as the whole thing is a bad joke, let us, at any rate, do our part; mitigate the sufferings of our fellowprisoners (Huxley again); decorate the

63. Ib1d., p. 43. 
dungeon with flowers and air-cushions; be as decent as we possibly can. Those ruffians, the Gods, shan't have it all their own way - her notion being that the Gods, who never lost a chance of hurting, thwarting and spoiling human lives were seriously put out if, all the same, you behaved like a lady... Later she wasn't so positive perhaps; she thought there were no Gods; no one was to blame; and so she evolved this athelst's religion of dolng good for the sake of goodness. 64

This "doing good for the sake of goodness" does not go too far with Virginia Woolf, however, remaining more on an intellectual and meditative level. She apparently is not a person to be overburdened with concern for the unfortunates in the slums or the starving Europeans. Yet her attitude does not seem cold blooded. The reader's sympathy is all with Mrs. Dalloway, who "cared much more for her roses than for the Armenians. Hunted out of existence, maimed, frozen, the victims of cruelty and injustice (she had heard Richard say so over and over again) - no, she could feel nothing for the Albanians, or was it the Armenians? but she loved her roses (didn't that help the Armenians?)"65 And a bitter picture indeed is painted of the professional do-gooder, the ugly, glowerlng Dorls Kilman, who "out of her meagre income set aside so much for causes she

64. Ib1d., p. 117-118.

65. Ib1d., p. 182 . 
belleved in. "66

Even the sympathetic Mrs. Ramsay who visits the poor with baskets admires without sharing her husband's sense of soclal responsiblitity: "He cared about fishermen and their wages. He could not sleep for thinking of them. It was altogether different when he spoke; one did not feel then, pray heaven you don't see how little I care, because one did care. "6?

What Virginia Woolf has to say, then, is not particularly cheering; most often the meditations of her characters on the problems of life and the universe seem to be rather morose and gloomy. This heaviness is lightened generally by an intense love of living, a deep appreclation of the possibilities of human relationships, and by a whimsical sense of humor which illumines all her writing. Traglcally, these tempering influences were not enough to hold back the tide of despalr in Virginia Woolf's own mind. Perhaps the "little dally miracles, the matches struck unexpectedly in the dark" were extinguished, leaving only the hopeless blackness. Like Clarissa, Virginia Woolf felt "theterror; the overwhelming incapacity, one's parents giving it into one's

66. Ib1d., p. 190.

67. Woolf, Virginia, To The L1ghthouse, p. 143. 
hands, this life, to be walked with serenity;

there was in the depths of her heart an awful fear."68 Unlike Clarissa, who somehow through Septimus' death felt that she was saved, that she could and must go on, Virginia Woolf did perish, and by her own hand, seemingly unable to face up to life's demands and largely overwhelmed by the intolerability of her own IIfe.

68. Woolf, Virginia, Mrs. Dalloway, p. 28. 
Virginia Woolf's style, always unique, is never w1 thout design, but generally the result of painstaking effort to find the best possible way of conveying exactly what she wanted to express. There is much preoccupation with the consciousness of her characters, w1th their relationships to each other and with their lives as staged against a background of the mysteries of time and experience. Virginia Woolf's belief was almost one of fervor in the hopelessness of ever really knowing another individual; she was certaln, w1thout too much conviction, of the transience and relative inconsequence of all concrete things. Such notions and emotions demanded a different technique from that of any ordinary writer; e. g., from one who has an intricate and charming story to tell, or the writer with a social message to explo1t, or the more partisan author who seeks to enforce a particular philosophical point of view.

Imaginative, poetic, impressionistic, whimsical, materlalist1c, - all these words might be used in any serious attempt to sum up the effect of Virginia Woolf's 
style. Her sensitive touch colors her prose with a thoughtful, dellcate shade which varies with the degree of emotional intensity. There is an easy flow of words as she subtly bullds up a mood or feeling; brief simplicity and lyrical lmagery are found side by side in impressive contrast.

There is a marked change in the style of Virginia Woolf's later books from her earlier works. The Voyage Out and Night and Day Indeed are constructed like any conventional novel, even to the point of over-striving for the supposedly necessary plot complications. In Jacob's Room, however, V1rginia Woolf breaks away from the traditional style, evidently inspired by her belief, expressed in The Common Reader, that the novelist's first duty is to present life as it $1 \mathrm{~s}$, recording the atoms as they fall, tracing the disconnected pattern, including any and all feelings and thoughts.

Apparently Virginia Woolf felt that this carefree method was not too successful; 11fe was st1ll elusive, and a more disclplined method was necessary to portray it effectively. In Mrs. Dalloway and To The Lighthouse there is a shift from merely recording the atoms as they fall to noting the patterns in which they fall. As a result, a more integrated form, a smoother flow and a 
clearer view of the human consclousness are afforded, so that her dual problem of "flux and form" is most satisfactorily solved, and at the same time her lyrical, dellcate style is enhenced rather than obscured.

Perhaps one of the most interesting features of her writing is the constantly shifting point of view which she employs. Virginia woolf seems to occupy a position midway between that of the traditional author who reports action, and the completely untraditional novelist, such as Joyce, who stays wholly in the mind of his characters. Although the consciousness of her characters is the important thing, still Virginia Woolf herself can be seen through the various shifts; she never entirely releases her own control of the thoughts of the characters. This more personal treatment of the stream of consciousness gives a subjective, rather impressionistic effect. Virginia Woolf herself can be seen brooding over life through the person of her characters, so much so that her novels take on a poetic quality.

In Jacob's Room we see much more of Virginia Woolf as the author than in the other two books. She even talks to the reader as she includes him in her thoughts. Conversationally, she watches Jacob as he walks down Shaftesbury Avenue. "He has turned to go. As for 
following him back to his rooms, no - that we won't do. Yet that, of course, is precisely what one does."I She herself observes the passing scene, with its multitude of people who really are irrelevant to her story. The many poetic interludes interspersed through the book come directly from her. With an impressionistic touch she paints the scene for the reader:

The snow, whlch had been falling all night, lay at three o'clock in the afterover the flelds and the hill. Clumps of withered grass stood out upon the hill-top; the furze bushes were black, and now and then a black shiver crossed the snow as the wind drove flurries of frozen particles before 1t. The sound was that of a broom swe eping - sweeping.

The stream crept along by the road unseen by anyone. Sticks and leaves caught in the frozen grass. The skin was sullen grey and the trees of black 1ron. Uncompromising was the severity of the country. At four o'clock the snow was again falling. The day had gone out.2

Virginia Woolf provides most of the philosophical thoughts of Jacob's Room, leaving the impression at times that she has momentarily forgotten her characters. Thus the sight of Fanny Elmer sitting for a portralt prompts the thought that "As for the beauty of women, It is like the light on the sea, never constant to a single wave. They all have it; they all lost 1t...thus

1. Woolf, Virginia, Jacob's Room, p. 159.

2. Ibid., p. 165 . 
if you talk of a beautiful woman you mean only something flying fast which for a second uses the eyes, I1ps, or cheeks of Fanny Elmer, for example, to glow through. "3 A belief in life after death through the places and people with whom we have assoclated, wonder at the Impossibility of "reaching, touching, penetrating the individual heart, "4 recognition that nature sometimes satisfies when "as for men and women, let them go hang, "5- these represent Virginia Woolf's thoughtful reflections.

In the other two books, however, her technique largely changes. The point of view is nearly always that of one of the characters; yet at the same time there is a sort of playing with the point of view. Especially in Mrs. Dalloway, it is frequently difficult to declde just who is doing the thinking, the observing, or the philosophizing. The opening sentence states that Mrs. Dalloway would buy the flowers herself, "For Lucy had her work cut out for her. The doors would be taken off their hinges; Rumpelmeyers's men were coming. And then, thought Clarissa Dalloway, what a morning -

3. Ib1d., p. 195.

4. Ib1a., p. 156.

5. Ib1d., p. 239. 
Iresh as if issued to children on a beach. "6 Already the question ralses itself whether Virginia Woolf is explaining about the busy day or whether we have entered Mrs. Dalloway's consclousness. The tucked-in "thought Clarissa Dalloway" would lead to the latter conclusion. Later on, lonely and bewlldered by Septimus' actions, Rezia "put on her new hat and he never noticed; and he was happy without her. Nothing could make her happy without him! Nothing! He was selfish. So men are." Though at first glance the author seems to be traditionally interpreting for the reader, again the probability is that the point of view belongs to Rezia, not to Virginia Woolf.

One galns the impression that Virginia Woolf does not feel justifled in entering the scene too much, but that occasionally she almost slips into giving an opinion or an emotion, then covers up by attributing that opinion or emotion to one of her characters. Thus she writes that "one feels even in the midst of the traffic, or wak1ng at n1ght," - then carefully set in "Clarissa was positive, a particular hush or solemnity...

6. Woolf, Virginta, Mrs. Dalloway, p. 3. 7. Ib1d., p. 34 . 
before Big Ben strikes. "8 As Peter leaves Clarlssa's house, "stlence falls on London; and falls on the mind. Effort ceases. Time flaps on the mast. There we stop; there we stand. Rigid, the skeleton of habit alone upholds the human frame;" - then, Peter suddenly controls the point of view: - "where there is nothing, Peter Walsh sald to himself, feeling hollowed out, utterly empty within. "9

This is done at times with a kind of whimsical touch of humor, and Virginia Woolf will ascribe a certain sentiment to a character who does not really seem capable of such a delicate thought. Thus Ellzabeth is described: "She was like a poplar, she was like a river, she was like a hyacinth," - and, almost as an afterthought - "Willie T1tcomb was thinking." 10 We cannot help wondering if it is not Virginia Woolf rather than Willie who would describe Elizabeth in such terms, and that it is she again, instead of Mr. Bentley, who would think of the disappearing aeroplane as a "bright spark; an asplration, a concentration; a symbol (so it seemed to Mr. Bentley, vigorously rolling his strip of turf at Greenwich) of man's soul. "ll

8. Ib1d., p. 4.

9. Ib1d., p. 74.

10. Ib1d. , p. 287.

11. Ib1a., p. 40. 
Often too in the midst of a character's thoughts there is a rather exaggerated use of the simile or metaphor, which may, or may not, be part of the character's stream of consclousness - and may, or may not, have been inserted by Virginia Woolf. So Peter recalls his refusal by Clar1ssa: "It almost broke my heart, too, he thought; and was overcome with his own grief, which rose like a moon looked at from a terrace, ghastly beautiful with light from the sunken day. "12

Again in To The Lighthouse the point of view shifts from character to character, yet again it seems that Virginia Woolf too enters in. Especially does this seem true with the reactions and thoughts of Lily Briscoe, the artist visiting the Ramsays, who seems placed in the book almost for the express purpose of musing about the other characters and constantly questioning the eternal problems of IIfe and human experience. Her conclusions mostly are those that Virginia Woolf herself would reach. Resting for a moment, she wonders about the meaning of life, "the general question whlch was apt to particularise 1 tself as such moments as these":13

That was all - a simple question; one that tended to close in on you with

12. Ib1d., p. 62 .

13. Woolf, Virginia, To The Lighthouse, p. 240. 
years. The great revelation had never come. The great revelation perhaps never did come. Instead there were little dally miracles, llluminations, matches struck unexpectedly in the dark; here was one. This, that and the other... In the midst of chaos there was shape; this eternal passing and flowing (she looked at the clouds going and the leaves shaking) was struck into stability. 14

Such an illumination is experienced by Clarissa Dalloway as she sees the old woman next door golng to bed. Terrifically shaken by the news of the unknown young man's sulcide, she contrasts herself with h1m, overcome by a sense of gullt because he had thrown life away, had defied old age, whereas "she had once thrown a shilling into the Serpentine, never anything more."15 Then, watching her nelghbor, "She felt somehow very like him - the young man who had killed himself. She felt glad that he had done it, thrown it away. The clock was striking; the leaden circles dissolved in the air. He made her feel the beauty; made her feel the fun. But she must go back. She must assemble." 16

In somewhat the same manner L1ly Briscoe is enabled to finish her painting at the precise moment that she and Mr. Carmichael come 1nto sympathy with each other, and at the moment that Mr. Ramsay and his children reach

14. Ib1d., p. 240-241.

15. Woolf, Virginia, Mrs. Dalloway, p. 280.

16. Ibid., p. 284. 
an understanding:

She looked at her canvas; it was blurred. With a sudden intensity, as if she saw it clear for a second, she drew a Iine there, in the center. It was done; it was finished. Yes, she thought, laying down her brush in extreme fatigue, I have had my vision. 17

These shifts of character to character are done quite smoothly, and usually with logical sequence. Evidently V1rginia Woolf felt that such transition connecting the eplsodes with a certain fluidity, tended to convey her mood of reverle, as she developed this more in the later books than in Jacob's Room. Here the eplsodes are often completely disconnected, w1 the Irrelevance of happenings belng really played up. The point of view often changes from one character to another, from one scene to another, from one time to another, with scarcely any logical connections. Although perhaps the pure stream of consciousness technique is full of such irrelevancies, yet in Mrs. Dalloway and To The Lighthouse the story moves along with much more ease and grace because of the easy transitions. Instead of becoming a serles of 1solated episodes, there is a sense of completion, of wholeness, of an uninterrupted reverie which flows on continuously.

17. Woolf, Virginia, To The Lighthouse, p. 310. 
Frequently it is the specific time of day that serves as a connecting link between characters. "Twelve o'clock struck as Clarissa Dalloway laid her green dress on her bed, and the Warren Smiths walked down Harley street. Twelve was the hour of their appointment." 18 The clock strikes three as Richard enters Dean's Yard, coming from Lady Bruton's Iuncheon. "Lunch parties waste the entire afternoon, he thought, approaching his door. The sound of Blg Ben flooded Clarissa's drawing room, where she sat, ever so annoyed, at her writing table."19 The clock striking 4:30 a minute late reminds Clarissa of all the little detalls to be arranged for her party; the same late clock striking, with its "lapful of odds and ends seemed to break like the spray of an exhausted wave upon the body of Miss K1lman. "20

Sometimes it is the sight of a certain object or a given person which joins the characters. In To The Lighthouse the reader shifts from Lily's consciousness to that of $\mathrm{Mr}$. Bankes as both see Mr. Ramsay looking at the sea, then walking away. 21 The point of view is $\mathrm{Mr}$.

18. Woolf, Virginia, Mrs. Dalloway, p. 142. 19. Ib1d., p. 178.

20. Ib1d., p. 194.

21. Woolf, Virginia, To The Lighthouse, p. 71. 
Ramsay's at the end of one eplsode because he sees his wife get her green shawl; the next section begins w1th Mrs. Ramsay: "She folded the green shawl about her shoulders. She took his arm. "22 Walking along with Mr. Ramsay, she wonders "Was that not Lily Briscoe strollIng along with W1lliam Bankes?" And thus the scene shifts: "He had been to Amsterdam, Mr. Bankes was saying as he strolled across the lawn with Lily Briscoe." 23 The use of time is quite interesting in Virginia Woolf's writings, especially in Mrs. Dalloway, where the whole story takes place during twelve hours, and where we are constantly made aware of the time of day. The Inevitability of the passage of time is emphasized not only by the recurrence of the time references, but also by the repeated use of such phrases as "First a warning, musical; then the hour, irrevocable."24 An 1mpression of the fluidity of time and experience is gained by repeated descriptions of the sound of the striking clocks dying away in the distance:

It was precisely twelve o'clock; twelve by Blg Ben; whose stroke was wafted over the northern part of London; blent with that of other clocks, mixed in a thin ethereal way with the clouds and wisps of smoke, and died up there among the seagulls...

22. Ib1d., p. 100.

23. Ib1d., p. 109.

24. Woolf, Virginia, Mrs. Dalloway, p. 5, 177. 
The leaden circles dissolved in the a1r. 2.5

This mood of transition, of constant flow, of change, is evident also in Virginia Woolf's writing in her repeated use of metaphors which stress the fleeting and the impermanent. Rezla, sitting alone, speaks aloud, and no one answers. "There was nobody. Her words faded. So a rocket fades. Its sparks, having grazed their way into the night, surrender to 1t. Dark descends, pours over the outlines of houges and towers."126 Later, with Septimus, "She sighed as she sat sewing. Her sigh was tender and enchanting, like the wind outside a wood in the evening. "27

In a mood of expectation Clarissa thinks how fresh and calm the alr was in the early morning, "like the flap of a wave; the kiss of a wave." 28 The thought of a calm, engulfing stream recurs to her in the flower shop, as she feels that the beauty and pleasant scent "were a wave which she let flow over her and surmount that hatred." 29 Quiet again descends on her as she sews: "So on a summer's day waves collect, overbalance and fall; collect and fall;

25. Ib1d., p. 142.
26. Ib1d: p. 34.
27. Ib1d., p. 214.
28.
29. Ib1d., p. 3.
Ib1d., p. 19.


fear no more, says the heart, commltting 1 ts burden to some sea, whlch sighs collectively for all sorrows, and renews, beglns, collects, lets fall. "30

The important looking motor car which drives mysterlously down the street leaves curlosity in its wake: "Rumors were at once in circulation, passing Invisibly, inaudibly, like a cloud, swlft, vell-like upon hills, falling indeed with something of a cloud's sudden sobriety and stiliness upon faces which a second before had been disorderly." 31

These references to the water, wind, clouds, rockets and smoke, all transient and ever-chenging, blend in harmony with Virginia Woolf's mood of the ebb and flow of I1fe.

Virginia Woolf seems to have a mystic sense concerning the passing of time. Actual events and experiences lose their 1mportance and are regarded in a sort of mysterlous perspective which shrouds them in opaqueness. The things that really count are thoughts, relationships, memories and dreams rather than the more concrete actions. The consuming of a decade in the midale section of To The Lighthouse is quite a contrast in this respect to the other two sections, each of which is composed of a single

30. Ibid., p. 59.

31. Ib1d., p. 20. 
day, whth thoughts and events given in great detail. The ten years just drift by in shadowy indistinct fashion, without chronological emphasis. Lyrical, Imaginative interludes concerning the seasons or the empty house and the sea, recelve much more attention than the few facts concerning the characters, which are considered so unimportant that they are enclosed in parentheses. Mrs. Ramsay, really the main character of the book, dies durling these ten years, but the fact of her death is told us as if by afterthought, with no deta1ls: "Mr. Ramsay, stumbling along a passage one dark morning, stretched his arms out, but Mrs. Ramsay having died rather suddenly the night before, his arms, though stretched out, remained empty." 32 How different th1s is from the preceding paragraphs, where the winter geason dominates the scene:

Night, however, succeeds to night. The winter holds a pack of them in store and deals them equaliy, evenly, with indefatigable eingers. They lengthen; they darken. Some of them hold aloft clear planets, plates of brightness. The autumn trees, ravaged as they are, take on the flash of tattered flags kinkling in the gloom of cool cathedral caves where gold letters on marble pages describe death in battle and how bones bleach and burn far away in Indian sands.

32. Woolf, Virginia, To The Lighthouse, p. 194. 
The autumn trees gleam in the yellow moonlight, in the light of the harvest moons, the light which mellows the energy of labour, and smooths the stubble, and brings the wave lapping blue to the shore. 33

This feeling of the relative insignificance, even actual intrusion, of external movement and action is reflected in Virginia Woolf's style in several ways. The frequent parentheses, sometimes casual, often whimsical, are used to report some direct action right in the midst of a more imaginative, thoughtful section, or alrectly from a character's stream of consciousness. Events which to traditional writers would be important enough to demand real attention are often merely hinted at, and then so included in the text that the very casual reader might miss them altogether. Fanny's love for Jacob is revealed from Jacob's point of view: "And Jacob was afraid of her for a moment - so violent, so dangerous is it when young women stand rigid; grasp the barrier; fall in love." 34 And with no more attention paid to poor Fanny's love, the author goes on to speak of Hampstead Garden Suburb. Finally there is her extreme simplicity and brevity of statement which generally accompanies portrayal of action as contrasted with the much more detalled lyrical passages; in these every

33. Ibid., p. 192 .

34. Woolf, Virginia, Jacob'g Room, p. 200. 
effort is made to build up for the reader a specific mood or emotion.

In Virginia Woolf's writing there is practically none of the author's reporting to the reader concerning a character's appearance, personality, and "true self," since Virginia Woolf belleves that there is no way one person can be absolute judge of another. "How then, Lily had asked herself, did one know one thing or another about people, sealed as they were?" 35 Again, from Jacob's Room, "It seems that a profound, 1mpartial, and absolutely just oplnion of our fellow creatures is utterly unknown. "36 As Virginia Woolf expresses this thought in words, so she shows it in her characters, for the picture that we get of them is a composite one, gathered together from varying impressions of others. All of her characters are revealed elther by the1r own thoughts and emotions or by the way in which they impress other people, and the reader seldom galng only a single Impression of a character.

In the rather loosely kn1t Jacob's Room the Impression is given that the only reason for bringing in most of the other characters at all, is that the reader can see how they are affected by Jacob. He is seen as 
perfect by Fanny Elmer, as sweet but a little young by Sandra Wentworth Williams, and as a best friend, though romantic and somewhat stupld by Bonamy. Lily Briscoe, in To The Lighthouse, expresses the difficulty of tryIng to sum up her impression of other characters:

How then did 1 t work out, all this? How did one judge people, think of them? How did one add up this and that and conclude that it was liking one felt, or disliking? And to these words, what meaning attached, after all?... You have greatness, she continued, but Mr. Ramsay has none of 1t. He 1s petty, seli1sh, valn, egotistical; he is spoilt; he 1s a tyrant; he wears Mrs. Ramsay to death; but he has what you (she addressed Mr. Bankes) have not; a flery unworldliness; he knows nothing about trifles; he loves dogs and his children......All of this danced up and down, like a company of gnats, each separate, but all marvellously controlled in an invisible elastic net danced up and down in Lily's mind. 3 ?

Yet with every allowance for lluidity, variation and change 1t would be Indeed an error to suppose that Virginia Woolf's writing moves along on a shadowy, vague and even keel, for there is a great deal of emotional intensity in her prose. Her characters know both the helghts of bliss and the depths of depression and fear; oftentimes their feelings are described most minutely and vividiy, and at other times there is a fervor that borders on exaggeration. In the opening pages of To The L1ghthouse we see James, the slx year old son of the

37. Woolf, Virginia, To The Lighthouse, p. 40-4l. 
Ramsays, cutting out a pleture of a refrlgerator which 1s "endowed with heavenly bliss. It was fringed with joy, "38 all because of the simple fact that he plans to v1sit the lighthouse the next day. Upon the dampening statement from his father that it may not be a fine day, "Had there been an axe handy, or a poker, any weapon that would have gnashed a hole in his father's breast and killed $\mathrm{hlm}$, there and then, James would have seized 1t." 39 Virginia Woolf explains his intense emotions with the statement that

he belonged, even at the age of six, to that great clan which cannot keep this feeling separate from that, but must let future prospects, with their joys and sorrows, cloud what is actualiy at hand, since to such people even in earliest childhood any turn in the wheel of sensation has the power to crystallize and transfix the moment upon which 1 ts gloom or radiance rests. 40

She thus seems to believe that some people are affected strongly by words or events whlch to others would be casual and trite, yet she strives to be utterly honest in her treatment of emotion. The very simple fact that Lady Bruton had Invited Richard to Iunch without including her causes Clarlssa to feel "suddenly shrivelled, aged, breastless: "4l

38. Ib1d., p. 9.

39. Ib1d. p. 10.

40. IbId., p. 9.

41. Woolf, Virginia, Mrs. Dalloway, p. 45. 
"Fear no more," said Clarissa. Fear no more the heat $o^{\prime}$ the sun; for the shock of Lady Bruton asking Richard to lunch without her made the moment in which she had stood shiver, as a plant on the riverbed feels the shock of a passing oar and shivers: so she rocked: so she shlvered. 42

A definite tonal coloring is given to Virginia Woolf's books by her device of repetition of word patterns. Like a reiterated theme in a symphony are such phrases from Mrs. Dalloway as "fear no more," "alone forever," "human nature is upon you," "the death of the soul," and "the leaden circles dissolved in the alr." Virginia Woolf also gives a great deal of cumulative detall which adds not only to the poetic effect, but to the complete tonal theme of the book. Buoyantly, joyously walking along, Clarissa reflects that

In people's eyes, in the swing, tramp, and trudge; in the bellow and the uproar; the carriages, motor cars, omnibuses, vans, sandwich men shuffling and swinging; brass bands; barrel organs; in the triumph and the jingle and the strange high singing of some aeroplane overhead was what she loved; Ilfe; London; this moment of June. 43

The rhythm and the lyrical touch of this passage seem more akin to a poem than to a novel. On reviewing these various features and facets of style it becomes increasingly clear that Virginia Woolf

42. Ib1d., p. 44. 43. Ib1d., p. 5 . 
was continually striving to acquire the particular technique which would best fit her for expressing her inner self. In Jacob's Room, the earliest of the three books, a growing use of experimentation seems to be apparent. While the imaginative passages, the vlewing of character through the impressions of others and the importance of the consclousness rather than the external actions are all present, Virginia Woolf had not yet worked out the sense of completion and wholeness and that smooth flow and more impersonal style which are developed in Mrs. Dalloway and To The Llghthouse.

In Mrs. Dalloway plot and characters are more fully developed. Packed into the limits of one day, the story is told from the point of view of the various major characters, along with the frequent use of reminiscence. In many respects Mrs. Dalloway might be considered Virginia Woolf's best book. I belleve that in any event it has the most popular appeal. Less attention is pald to the plot in To The Lighthouse, in which a group of characters is viewed for one day and then again, most of them, ten years later. W1th her subtle and 1maginative insight Virginia Woolf has gone further here in her questioning, her pondering on the symbollc relationship of her characters to each other and to the larger mysteries of life, death and time. 
These shifting points of view, the emphasis on transition and transience, her indirect method of character interpretation, and the Iyrical intensity of her prose all seem eminently suited to be a means to the end of self-expression and for exhibiting the sensitive perceptions of Virginia Woolf. One leaves her subtle, poetic prose and its rather haunting overtones, with the growing conviction that she has made a permanent contribution to creative, narrative novel, and with a glow of satisfactory enrichment because of the style that Virginla Woolf developed and glorified. 
CONCLUSION

As one studies all the published writings of Virginia Woolf and reads the avallable criticism, some very definite conclusions emerge that make one loath to leàve her and the distinct literary excellencies she has created. There are certain patterns which stand out more definitely and uniquely as one gets behind surface impressions and discovers her motives and delights in her methods.

What, then, is that design that takes form as we seek to weave together all the mult1-colored threads that enter into the production of Virginia Woolf's literary fabric? Perhaps first of all there is the pattern of a novel1st who, whlle consclous of the weaknesses of contemporary 11terature, yet labored diligently to portray life itself as she had envisioned it in her mind of many moods.

Virginia Woolf certainly was moody and at times v1sionary; but to claim that her storles are vague and her characters unreal is simply to proclaim a hasty or superficial study of her novels. It is true that she 
seldom followed any neatly prearranged schemes, elther in her stories or characters; but Virginla Woolf wrote as she did because she was picturing life as she believed life was. She was never experimentally groping in order that haply she might find the expressions and reactions of her persons; rather she was continually emphasizing the psychology of real human beings as she belleved they would or did behave in a given situation. There is always a haunting fascination about Virginia Woolf's portrayals that leaves the reader with the conviction that her characters ald or should respond as she has them doing.

The general charge, almost unlversally made, that Virginia Woolf's range was limited is not so literally true as appears on the surface. Virginia Woolf seems purposely to have limited her range in order that she might develop intensely what she belleved to be the more 1mportant life issues. There surely was for her the problem simply of being alive and facing the difficulties and perplexities that inhere in life as such. Then there was the necessity of adjusting to other selves as well as seeking to harmonize her own inner conflicts. Finally also there was the ever present problem of creeping old age followed by an inevitable death that ended all 
existence; for seemingly to Virginia Woolf there was never a thought of that immortality which sustains other writers even if it does not enrlch their writing. Her own intelligence and her acquaintance with a rather wide group of men and women of like culture - the upper midde class - while it would tend to limit her range, yet would produce a higher level of excellence than if she had extended her considerations to those about whom she knew less and for whom she cared little; for Virginia Woolf, any psychological problem was infinitely more captivating and demanding than were those of a soctal nature. Ne1ther royalty nor the poorer classes seemed to enter seriously into her thinking or to color her Iinished product.

While Virginia Woolf was thoroughly conversant with the thought life of her group and the times, yet she was never an 1mitator; she not only created a style or presentation but she gave that style a vogue and a volce that singles her out, perhaps, from among all the novelists of the present century. Steadily, almost from her intial efforts, she progressed within her self-wrought style, out of an atomic impressionism into what she envisioned as essential experience; that is, she grew away from the burdens and distraction of multi- 
tudinous detall, and came to the more satisfying because personal level of experimental essence.

V1rginia Woolf's novels are not to be forgotten; there is always something indefinably compelling and moving about all of her novels. One first reads to ascertain what is there, but one rereads for sheer delight and because of an almost haunting attraction that both her stories and characters give. The problems she presents are truly life - her life; they are not only her problems but they become the reader's problems. The moods and meditations of her characters steal into the reveries of the reader long after words and page are forgotten; yet certain phrases, many sentences and an occasional paragraph sear themselves into the undying memory.

Virginia Woolf's contribution to the repertolre of I1terature is abidingly real, not only in the new technique she advanced but likewise in the stories themselves. What an anti-climax that one so full of vitality and so richly lmbued with the zest for life in its many areas and phases should at the same time so feel the terror and the enigma of her rather small world of here and now, that its cruelty, 1ts cold 1mpartiality, 
and to her its unprincipled vastness could cause that tragle ending of her life by her own act, and seemingly according to any expressed view, the ending of her self. 


\section{BIBLIOGRAPHY}

Beach, Joseph, The Twentleth Century Novel, The Century Co., New York, London, 1932.

Bennett, Joan, V1rg1nia Woolf, Harcourt, Brace, and Co., New York, 1945.

Burgum, Edwin B., The Novel and The World's Dilemma, Oxford UnIversity Press, New York, 1947.

Daiches, Dav1d, The Novel and the Modern World, The University of Chicago Press, Chicago, 1939.

Dalches, Davia, Virginia Woolf, New Directions Books, Norfoik, Conn., 1942.

Delattre, Floris, Le Roman Psychologique de Virginia Woolf, Libralrie Philosophique J. Vrin, Paris, 1932.

Forster, E. M., Virginia Woolf, Harcourt, Brace and Co., New York, 1942.

Kunttz, S. J., and Haycraft, H., Twentleth Century Authors, N. W. Wilson Co., New York, 1942.

Muller, Herbert, Saturday Review of Literature, "V1rginia Woolf and Feminine Fiction", Vol. 15, No. 15, Feb. 6,1937 .

Woolf, Virginia, The Common Reader, Harcourt, Brace and Co., New York, 1925.

Woolf, Virginia, Jacob's Room, Harcourt, Brace and Co., New York, 1923.

Woolf, Virginia, Mrs. Dalloway, Harcourt, Brace and Co., New York, 1925.

Woolf, Virginia, To The Lighthouse, Harcourt, Brace and Co., New York, 1927. 